\title{
Measuring women's work: A methodological exploration
}

Ray Langsten

Rania Salem

Follow this and additional works at: https://knowledgecommons.popcouncil.org/departments_sbsr-pgy

Part of the Demography, Population, and Ecology Commons, Family, Life Course, and Society Commons, Gender and Sexuality Commons, International Public Health Commons, and the Work, Economy and Organizations Commons How does access to this work benefit you? Let us know!

\section{Recommended Citation}

Langsten, Ray and Rania Salem. 2006. "Measuring women's work: A methodological exploration," working paper. Cairo: Population Council. 


\title{
Measuring Women's Work:
}

\section{A Methodological Exploration}

\section{A Working Paper}

\author{
Ray Langsten \\ Social Research Center \\ American University in Cairo \\ Cairo, Egypt \\ and \\ Rania Salem \\ Office of Population Research \\ Princeton University \\ Princeton, NJ USA
}

28 February 2006

This research was conducted under Phase I of the project "Slowed Fertility Transition in Egypt" conducted in 2004 by the Population Council West Asia and North Africa regional office in Cairo. That phase of the project was funded by the U.S. Agency for International Development, under the terms of Cooperative Agreement number HRN-A-00-99-00010. The opinions expressed herein are those of the authors and do not necessarily reflect the views of the U.S. Agency for International Development. Support was also provided by grants from the Mellon Foundation and CIDA to the Population Council regional office in Cairo. 


\title{
Measuring Women's Work: A Methodological Exploration \\ Ray Langsten and Rania Salem
}

\begin{abstract}
In this paper we contrast two approaches to the measurement of women's work applied to the same population of ever-married women. These women were interviewed on two separate occasions - first during the 2003 Interim Egypt DHS, and again during the Slow Fertility Transition (SFT) survey conducted in 2004. The DHS uses a standard keyword question to measure work, while the SFT employs an activities list question format. We argue that the widely-used keyword approaches to measuring women's work underestimate the level of female labor force activity, as shown by the DHS-SFT comparison and supported by analysis of data from the 1998 Egyptian Labor Market Survey. We demonstrate that the activities list approach captures a wider range of economic activities among women, while allowing us to document multiple jobs held simultaneously by respondents. Furthermore, we find that keyword questions disproportionately exclude poor and poorly educated working women from the labor force. Survey approaches to the measurement of women's work must be revised if we are to fully account for women's contributions to family welfare and national accounts, and if we are to understand the relationship of work to other variables and processes of interest to social scientists.
\end{abstract}




\section{Measuring Women's Work: A Methodological Exploration ${ }^{1}$}

\section{$\underline{\text { Introduction }}$}

The social science literature has long recognized that women's productive activities ${ }^{2}$ are poorly measured. Boserup (1970), writing more than three decades ago, is credited with first raising the question of whether women's work is accurately accounted for in labor force statistics (Beneria 1981; Beneria 1992). In the intervening years, scholars have often noted that women's work is under-reported in official data, censuses, and labor force surveys (Beneria 1981; 1982; Dixon 1982; Boulding 1983; Recchini de Lattes and Wainerman 1986; Papps 1992; Bajaj 1999 Chen, Sebstad and O’Connell 1999; Donahoe 1999), with some contending that “conceptual and statistical practices have made much of women's work “invisible"” (Standing 1999: 586; see also, Mehra and Gammage 1999; Carr, Chen and Tate 2000). Even in the present decade the problem of fully capturing women's work remains (Chen 2001; Salway, Rahman and Jesmin 2003). Yet, correct information on women's (and all) work is "crucial for diagnosing the causes of poverty and inequality—and for guiding policymakers in their attempts to improve living standards" (Schaffner 2000: 217). It is likely that unreported work makes a substantial contribution to family welfare and national accounts (Leila 2001) Moreover, employment status, occupation and income are widely used as predictors and as outcomes in the empirical work of the social sciences. The importance of measuring them properly is self-evident.

Two broad issues affect the measure of women's work: 1) the definition, or conceptual categories, used; and 2) the way in which the definition is operationalized for data

\footnotetext{
1 This analysis was partially supported by the Population Council through a grant from USAID_-Subaward number I04.12A. The authors wish to thank Rania Roushdy, Nahla Abdel Tawab, Zeinab Khadr, and Ragui Assaad for their advice on various aspects of this study. We are especially grateful to John Casterline, who provided extensive comments on an earlier version of the paper.

${ }_{2}^{2}$ In this paper we will focus on women's labor force activity, or women's work, not on women's labor force participation. The latter typically encompasses those who are unemployed, while we are concerned solely with fully measuring women's contribution to production (Anker 1990).
} 
collection (Dixon 1982; Papps 1992; Assaad 1997). In this paper we examine this second issue: data collection methods. We compare two surveys which share the same basic definition of work, but which differ in their approaches to measuring it. The first survey, the 2003 Egypt Demographic and Health Survey (EDHS) utilizes a keyword question, a format which is commonly used in many labor force surveys, as well as in all DHS. The second survey to which this is contrasted was administered to a sub-sample of the 2003 EDHS respondents in 2004, and uses an activities list. We argue that the activities list method provides a more accurate accounting of all forms of women's work, and permits a fuller assessment of women's economic contributions. We further demonstrate that the newly identified working women are different from the women categorized as working by standard questions used in most surveys.

\section{The Development of Current Conceptualizations and Measures of Work}

In the 1980s, much of the discussion of the definition of work focused on the contentious issue of including, or not, domestic work that contributes to family well-being (Beneria 1981;1982). But, beyond this unresolved problem, others have focused on the undercount of women working in agriculture (Dixon 1982), and, more recently, women in the informal sector (Charmes 1998; Bajaj 1999; Chen, Sebstad and O'Connell 1999; Mehra and Gammage 1999; Standing 1999; Carr, Chen, and Tate 2000; Chen 2001; Carr and Chen 2002; Muller 2002; Chen 2004; Avirgan, Bivens, and Gammage 2005). As a part of this discussion, the International Conference of Labor Statisticians revised and broadened the official definition of work in a resolution adopted in October 1982 (ILO 1982), and dealt with the issue of employment in the informal sector in a resolution adopted in January 1993 (ILO 1993). Most researchers now accept a broad definition of work including all activities that produce "goods and services designated as important elements of national wealth and 
economic growth" (Donahoe 1999: 544), no matter how temporary, intermittent or informal the work may be, or how little time is devoted to it (though some research imposes minimum numbers of hours worked per week). While there may still be tasks that are difficult to classify, ${ }^{3}$ it remains the case that most surveys of female labor force activity now seek to include all women who work in the broad, extended labor force, including those who produce only for home consumption and even if for only an hour or so per week.

Changes have also been made in data collection methods in order to ensure that respondents understand the definition of work used, and to encourage the reporting of all work by respondents. The standard approach to measuring women's work uses one or more "keyword questions"- employing such terms as "work", “job”, or "main activity" (Anker 1983). Although the keyword questions typically used in the labor market/force surveys have changed in accordance with the adoption of a broader definition of work, the new questions remain ineffective in capturing home-based and subsistence production, part-time sales, and other casual and intermittent activities. When researchers complain of under-reports of women's work, they are generally speaking of data collected using the keyword approach. To improve the capture of women's labor force activity, some have employed "time-use" studies, collecting detailed information on all activities, including work, leisure, sleep, etc., that a woman does during a given time frame (Donahoe 1999). An alternative approach for improving reports of work is the use of an activities list (Dixon 1982), in which the respondent is queried about a list of specific tasks - work in the fields; work in a factory or workshop; make cheese or sweets to sell; sell something in a shop, the market, or the street; etc. Anker and colleagues have shown such lists to have a substantial impact on the number of women workers reported in methods tests in Egypt and India (Anker, Khan and Gupta 1987;Anker and Anker 1989; Anker 1990; Anker and Anker 1995). Despite the higher levels

\footnotetext{
${ }^{3}$ For example, while all may view home production of cheese for sale in the market as an important economic contribution, perhaps not everyone will agree about the inclusion of the making of dung cakes used as fuel in the making of the cheese.
} 
of women's work revealed by such alternative methods, time-use data are rarely collected, and activities lists are almost never used, Yet researchers continue to request that "survey instruments should be made more sensitive to women's work" (Mehra and Gammage 1999: 547; see also, Muller 2002).

\section{Women's Work in Egypt}

In the early 1980s Anker (1983) critiqued the contemporary definitions of, and data collection methods for measuring, women's work. In that same year, the Egyptian Labor Force Sample Survey (LFSS) made a conscious effort to improve reporting of women in the labor force, by specifically training interviewers to be aware of unpaid family labor, particularly labor on family farms (Anker and Anker 1989). As a result of these efforts, the percentage of women reported to be working doubled from 5.8 percent in 1982 to 12.7 percent in 1983 (Anker and Anker 1989: Table 3). But, it was argued that "further improvement in data collection [was] both possible and necessary" (Anker and Anker 1989: $515)$.

To test the effects of questionnaire design, among other factors, on reports of women's work, and to demonstrate that women's labor force activity was substantially greater than even the 1983 reports, the ILO/CAPMAS Labor Force Methods Test (LFMT) was carried out in late 1984. While this methods test assessed the impact of a number of factors on reporting of women's work, in this current paper, we focus on the type of questions employed to identify working women. Two approaches were tried: 1) multiple keyword questions; 2) an activities list. When a broad "extended" definition of the labor force was used, the methods test found that 80 percent or more of rural women were economically active. While "use of typical labor force questions that rely on key words or phrases such as 'main activity' and 'work' result in an enormous under-reporting of female labor force 
activity" (Anker and Anker 1989: 518), Anker concluded that either a "sufficiently long set of [specific] key-word questions or ... the use of an activity schedule" would provide an accurate measure of women's work (Anker and Anker 1989: 519).

Following this methodological work a special round of the LFSS was conducted in October 1988 (Fergany 1990). Among the main features of this survey were a careful definition of employment and a measurement approach using a direct keyword work question, supplemented by a series of 6 screening questions (Fergany 1990; Assaad and ElHamidi 2001). This produced an extended labor force activity rate of 42 percent for women. A similar approach employing multiple keyword questions was used in the 1998 Egyptian Labor Market Survey (ELMS), when 46 percent of women were found to be active in the extended labor force (Assaad and El-Hamidi 2001). Interestingly, the reported level of female labor force activity dipped in the LFSSes of 1990 and 1995, between the special surveys of 1988 and 1998. This has been attributed to a "waning effort" to carefully probe women's work, particularly participation in subsistence agriculture and informal activities (Assaad and El-Hamidi 2001; Assaad 2002). These LFSS/ELMS results are show in Figure 1, below.

Additional results in Table 1 reinforce the important contributions of both definition and data collection methods in determining reported women's labor force activity. On the matter of the definition of work, the LFMT and the ELMS provide estimates of both: 1) the "market" labor force, including only those workers who produce goods or services for the market or for barter; and 2) the "extended" labor force, including a wider range of workers, adding those who produce goods or services for home consumption (Assaad 2002: 6). 


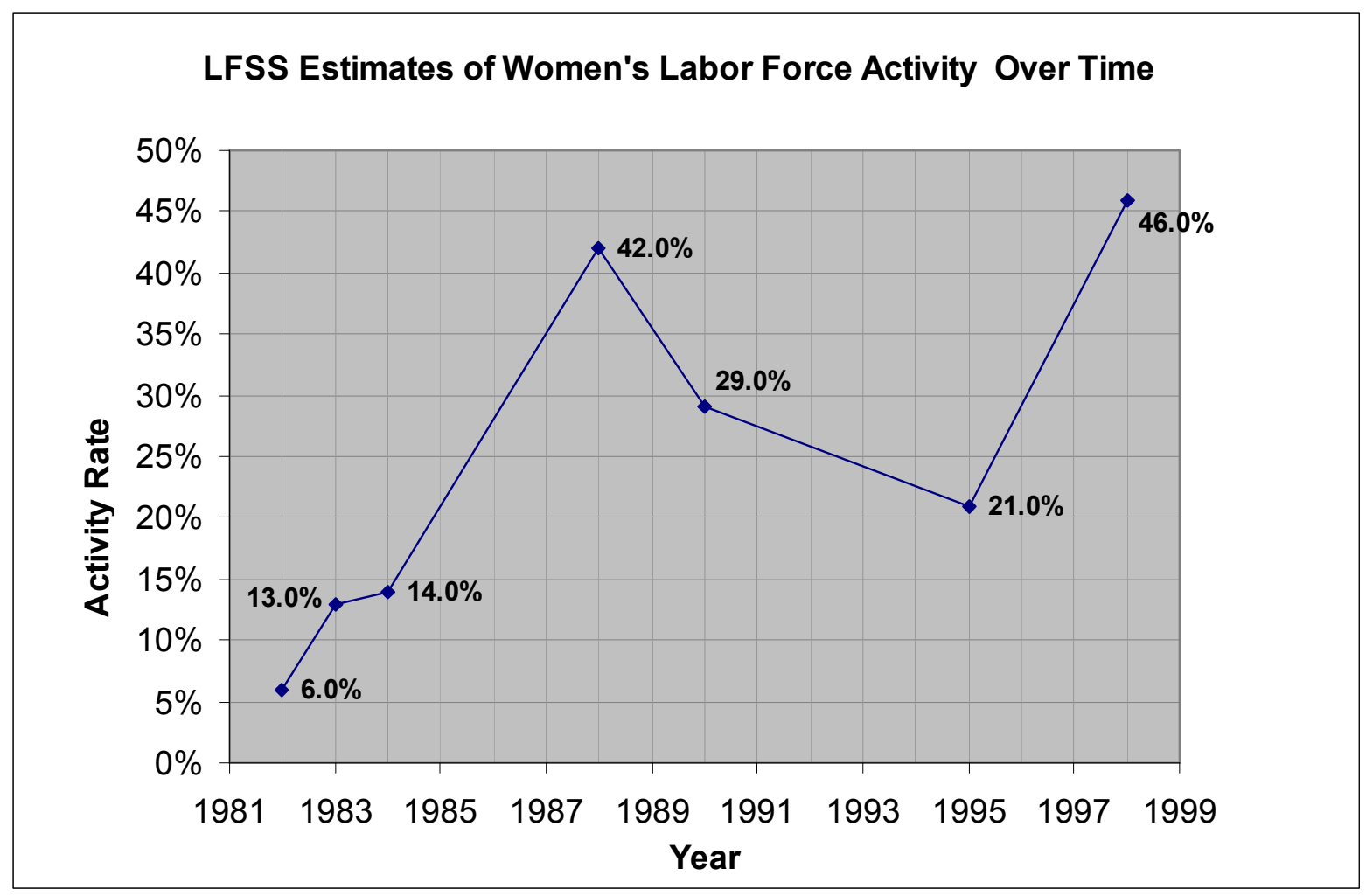

Both the ELMS and the LFMT found the market labor force to be about one-half the size of the extended labor force. However, in the LFMT data both measures of the labor force are almost twice those found in the ELMS, whichever definition is used.

Table 1. Levels of Women's Labor Force Activity in Egypt, According to a Variety of Sources.

\begin{tabular}{|l|c|c|}
\hline Survey & $\begin{array}{l}\text { Female } \\
\text { Participation Rate }\end{array}$ & Notes \\
\hline $\begin{array}{l}\text { ILO/CAPMAS Labor } \\
\text { Force Methods Test } \\
\text { Survey 1984 }\end{array}$ & $\begin{array}{c}83 \% \text { (Extended) } \\
40 \% \text { (Market) }\end{array}$ & $\begin{array}{c}\text { Rural women. } \\
\text { Multiple keyword questions, plus activities list. }\end{array}$ \\
\hline $\begin{array}{l}\text { Egypt Use } \\
\text { Effectiveness of } \\
\text { Contraception 1993 }\end{array}$ & $82 \%$ & Time-use approach. \\
\hline $\begin{array}{l}\text { Egypt Labor Market } \\
\text { Survey 1998 }\end{array}$ & $\begin{array}{c}46 \% \text { (Extended) } \\
21 \%(\text { Market) }\end{array}$ & Multiple keyword questions. \\
\hline
\end{tabular}

*Adapted from Assaad 2002: 10.

The LFMT achieves much higher levels of reported work not only because it used multiple keyword questions, but also because it included a basic activities list (Anker 1990). Indeed, Anker argues that "general keyword questions ... are not sufficient for identifying anything but the paid labor force" (Anker 1990:48). Donahoe (1999), analyzing time-use data, also finds levels of labor force activity as high as those reported by Anker. 
Keyword questions undercount women's work for a number of reasons. If, for example, an interviewer asks about "work", biases on the part of both the interviewer and the respondent may exclude unpaid family labor, and even part-time tasks done to earn money, from their normative conceptualizations of "work" (Dixon 1982; Anker 1983). These normative views of what should be counted as "work" may cause interviewers to forgo detailed probing into non-normative activities, in spite of their training (Anker 1990). Asking about "main activity" may lead many women to report themselves as "housewives", though they may make food products, or other goods that are sold in the market, and/or may spend some of their time selling these, or other, goods (Anker, Khan and Gupta 1987). This problem is aggravated when the woman's labor force activity is closely integrated with, and may be viewed as an extension of, her household duties. In effect, women's productive activities are hidden behind their normative economically inactive role of housewife and mother (Charmes 1998). Finally, women may be reluctant to report work they perform because it compromises their social status (Donahoe 1999).

\section{Methodology}

The core of our analysis compares the reported labor force activity rates of a sample of ever-married women between 15-49 years of age interviewed at two points in time, using two different measurement approaches. Each woman was first interviewed as part of the 2003 Egypt Interim DHS which used a standard keyword question. Approximately 10 months later, the same women were re-interviewed during the 2004 Slow Fertility Transition (SFT) survey in which a newly developed activities list was administered. (See Appendix 1 for the activity list used in the 2004 SFT survey.)

The work module of the 2003 DHS opens with a single keyword question: "As you know, some women take up jobs for which they are paid in cash or kind. Others sell things, 
have a small business or work on the family farm or in the family business. ... Are you currently doing any of these things or any other work? Have you done any work in the last 12 months?" This question clearly seeks to be inclusive of all work, whether for the market or for subsistence, whether full-time or part-time, The reference period used by the DHS is the 12 months preceding the interview. If the woman responded she had not worked during this period, no further probing was done by the interviewer and the woman was assumed to be economically inactive. If a woman responded that she had worked, she was asked for her occupation in a subsequent question. Those who worked in agriculture were also asked a question about the ownership of the land on which they worked, and then all working women were asked about the regularity of their work and the form of remuneration they received. As best as we can determine from the DHS questionnaire and data, only one job or type of work was recorded.

In contrast, the SFT activity list asked women about a number of possible economic activities, with women required to provide a response of "yes" or "no" to each item. The activities were loosely grouped into agricultural work, animal husbandry, production or processing for market exchange, and sale of own labor in various settings. We believe the conceptualization of work underlying these questions mirrors that of the DHS. If more than one type of work was reported in the SFT survey, women were asked to specify which economic activity they considered to be their main work. For this activity, information on hours worked outside the house and whether or not they were paid for their work was solicited from the respondents. The reference period for economic activities was shorter than the DHS; 3 months. Previous research suggests that such differences in reference period have little impact on the reported levels of women's work (Anker 1990).

In this paper, we first advance several hypotheses about our expected findings. Next we trace female work rates over time, showing how these rates respond to changes in the 
definition and operationalization of work in the DHS. In the following section, we explain our construction of a new set of categories of work status and occupation: "none", “professional/technical/clerical”, "sales”, “agricultural/ animal husbandry”, and "services/ manual", and display the overall work rates produced by the two surveys. We then examine the degree of correspondence between the levels of work reported in the DHS and SFT surveys. Next, we investigate the types of work most effectively captured by the activities list, and analyze the background characteristics of women who made consistent reports in comparison with those whose work status changed between the two surveys. For the latter, we focus particularly on newly identified workers; that is, those women who reported that they were not working in the DHS, but who were found to be economically active in the SFT. Finally we compare occupation-specific labor force activity rates for the ELMS and the SFT to show reporting differences between a survey that used multiple keyword questions and one employing an activities list.

\section{Hypotheses}

We hypothesize that the activities list approach identifies many more economically active women than do the single keyword questions typically used, and even than multiple keyword questions such as those in the ELMS.

We further hypothesize that particular sorts of employment will account for the bulk of the anticipated increase. Anker observes that almost all of the increase in women's labor force activity resulting from more detailed questions is concentrated in agriculture (Anker 1990: 30). Similarly, Assaad and Hamidi (2001) argue that variation in the periodic LFSS estimates of the female labor force is due in large part to variation in the coverage of female participation in agriculture. We expect that the SFT activities list will also identify many women involved in primary production (agricultural work/animal husbandry), particularly for 
home consumption. But we also expect to capture other types of work that are normally missed, such as manual labor, small-scale production, petty trade activities, and work performed for family-owned businesses. The work of women newly identified as active in the labor force is likely to be: intermittent, casual, home-based, part-time, in a wordinformal $^{4}$ (Kabeer 1997; Standing 1999).

Beyond the differences in the types of work performed by newly identified economically active women, we hypothesize that these women have different social and economic characteristics from working women detected by standard keyword questions. We posit that these newly identified workers will be poorer and less educated than are women who work in more normative positions and are identified by a single keyword question.

\section{Findings}

\section{Women's Work in DHS Over Time}

Before examining the 2003-2004 data it is useful to show how measures of women's labor force activity in the Egypt DHS have changed over time. In the first Egypt DHS, in 1988, the single keyword question used implied a limited market-oriented view of women's work. The 1988 question read: “Are you now doing any work for cash?” Apparently in response to the extensive debates on appropriate definitions of women's work, in 1992 DHS began to use the broader question noted above ${ }^{5}$ which reflects what Anker, Assaad, and others call the extended labor force.

\footnotetext{
${ }^{4}$ In this paper we use the term informal as a shorthand for the preceding characteristics. Labor economists have a formal definition for this term. According to the ILO, formal employment is: 1) stable, regular employment with a 2) registered enterprise, 3) secured by a contract and 4) covered by social insurance. Informal jobs under the ILO definition, lack one or more of these characteristics, and therefore have many elements in common with the informal work to which we refer in this paper (ILO 1993).

${ }^{5}$ This question reads: "As you know, some women take up jobs for which they are paid in cash or kind. Others sell things, have a small business or work on the family farm or in the family business. ... Are you currently doing any of these things or any other work? Have you done any work in the last 12 months?"
} 
Figure 2 shows the percent of women "currently working" for each DHS between 1988 and 2003. As expected, the narrow, market-oriented question used in 1988 produces a relatively low level of women's labor force activity - 13 percent. When the broader question was introduced in 1992, reported women's work increased to 21 percent, approximately the same level as was reported in 2003. But, reported women's labor force activity was lower in the DHS data for 1995 and 2000. It appears that, just as in the LFSS data collected between the two special surveys in 1988 and 1998, in the intermediate DHS years there was a waning effort to probe for women's work.

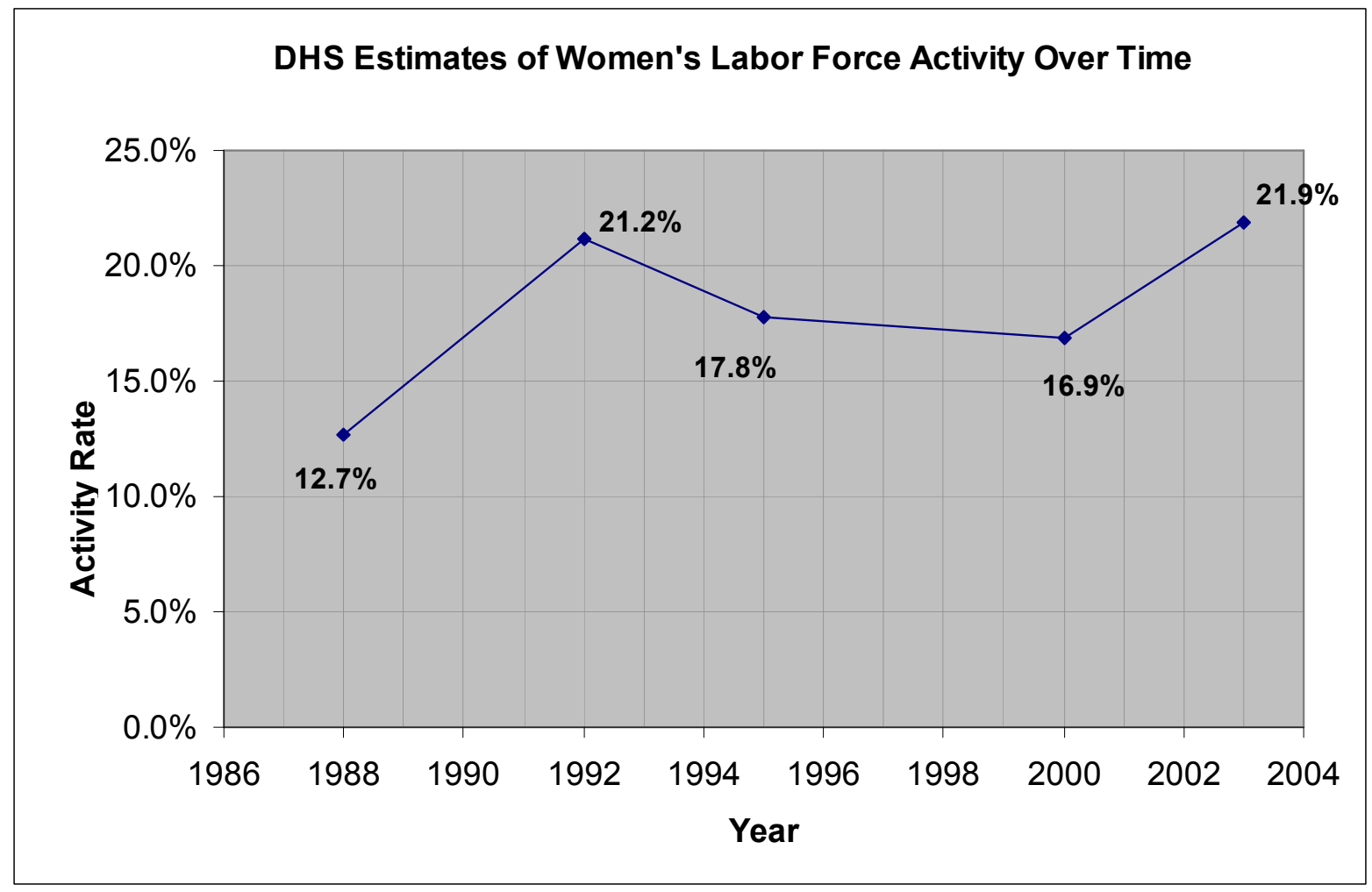

\section{Women's Work in the 2003 DHS and the 2004 SFT}

In this section we demonstrate that the questions used to measure women's work can have a substantial impact on the number of women identified as working and on the profile of women workers. Relying on a single keyword question, the 2003 DHS found a labor force activity rate of $20.8 \%$ in the sub-sample of ever-married women aged 15-49 who were 
included in the 2004 SFT survey. The more detailed work activities list employed by the SFT, on the other hand, indicates that $64.5 \%$ of these same women were working. The level of work captured by the question format used in the SFT is higher in both rural and urban areas, and in all regions. Table 2 below presents a cross-tabulation of reported work status found in the DHS 2003 and SFT 2004. We have grouped women into five work categories: 1) no work; 2) professional, technical or clerical (PTC); 3) sales (shop, souq ${ }^{6}$, or home); 4) agriculture or animal husbandry; 5) service or manual labor (skilled and unskilled). Because of the differences in the questions asked in the two sources of data, we are forced to recode the basic work variables and collapse occupational groups in both the DHS and the SFT to arrive at comparable categories.

In the SFT questionnaire women were able to report multiple occupations. As in other developing countries, in Egypt many women do more than one type of work. For example, women who make sweets may also sell those sweets in the souq. Or women who raise goats may make cheese from the goat's milk, and then sell the cheese from their homes. Some women will work in the fields when such work is available, but work in construction should an opportunity arise. In our recode of the SFT occupation variables, women who reported working at more than one job during the three months prior to the interview ${ }^{7}$ were assigned the occupation that they said was their "main work", that is, the work that was "most important" to them. If women reported (or were allowed to report) more than one type of work in the DHS, this is not evident from the DHS data set.

\section{Consistency and Change in the Two Measures of Work}

\footnotetext{
${ }^{6}$ Local market.

${ }^{7}$ Of the 2124 women who reported working the SFT, a total of 471 women $(22.2 \%)$ performed more than one job in the 3 months prior to the interview. Of these, more than half (276) do subsistence primary production (overwhelming animal husbandry), along with a market oriented task. Still, 195 women (9.2\% of all working women) performed more than one market oriented task during the reference period.
} 
Table 2, below, demonstrates two key conclusions. First, women who report that they are economically active in both surveys are generally consistent in reporting the same occupational activity at both points in time. The main difference between the two studies is that many women said to be economically inactive in the DHS are found to be working by the SFT activities list. Second, the DHS question on work is most effective in identifying women working in professional, technical and clerical (PTC) jobs: that is, jobs that are likely to be full-time or close to full-time, that are performed in an office setting in the so-called modern sector, and that conform to the normative view of "work". The SFT format, while identifying about the same number of PTC workers as the DHS does, disproportionately identifies women working in agriculture, and in sales, services, and manufacturing - jobs that are more likely to be casual, intermittent, and part-time, while being home-based and thus

Table 2. Comparison of Two Independent Reports of Work Status and Occupation- DHS 2003 and SFT 2004.

\begin{tabular}{|c|c|c|c|c|c|c|}
\hline $\begin{array}{l}\text { DHS } 2003 \\
\text { SFT } 2004\end{array}$ & A.None & $\begin{array}{l}\text { B.Professional } \\
\text { / Technical / } \\
\text { Clerical }\end{array}$ & C.Sales & $\begin{array}{l}\text { D.Agriculture/ } \\
\text { Animal } \\
\text { Husbandry }\end{array}$ & $\begin{array}{l}\text { E.Services/ } \\
\text { Manual }\end{array}$ & Total \\
\hline 1.None & $\begin{array}{l}1106 \\
94.8 \% \\
(.192) \\
\end{array}$ & $\begin{array}{c}22 \\
1.9 \%\end{array}$ & $\begin{array}{c}11 \\
0.9 \%\end{array}$ & $\begin{array}{c}12 \\
1.0 \%\end{array}$ & $\begin{array}{c}16 \\
1.4 \%\end{array}$ & $\begin{array}{c}1167 \\
100.0 \%\end{array}$ \\
\hline $\begin{array}{l}\text { 2.Professional } \\
\text { / Technical / } \\
\text { Clerical }\end{array}$ & $\begin{array}{c}25 \\
8.1 \%\end{array}$ & $\begin{array}{c}274 \\
88.7 \% \\
(.844)\end{array}$ & $\begin{array}{c}3 \\
1.0 \%\end{array}$ & & $\begin{array}{c}7 \\
2.3 \%\end{array}$ & $\begin{array}{c}309 \\
100.0 \%\end{array}$ \\
\hline 3.Sales & $\begin{array}{c}113 \\
66.9 \%\end{array}$ & $\begin{array}{c}6 \\
3.6 \%\end{array}$ & $\begin{array}{c}17 \\
10.1 \% \\
(.141)\end{array}$ & $\begin{array}{c}20 \\
11.8 \%\end{array}$ & $\begin{array}{c}13 \\
7.7 \%\end{array}$ & $\begin{array}{c}169 \\
100.0 \%\end{array}$ \\
\hline $\begin{array}{l}\text { 4.Agriculture/ } \\
\text { Animal } \\
\text { Husbandry }\end{array}$ & $\begin{array}{c}1168 \\
85.0 \%\end{array}$ & $\begin{array}{c}15 \\
1.1 \%\end{array}$ & $\begin{array}{c}9 \\
0.7 \%\end{array}$ & $\begin{array}{c}166 \\
12.1 \% \\
(.102)\end{array}$ & $\begin{array}{c}16 \\
1.2 \%\end{array}$ & $\begin{array}{c}1374 \\
100.0 \%\end{array}$ \\
\hline $\begin{array}{l}\text { 5.Services/ } \\
\text { Manual }\end{array}$ & $\begin{array}{c}184 \\
67.6 \%\end{array}$ & $\begin{array}{c}12 \\
4.4 \%\end{array}$ & $\begin{array}{c}4 \\
1.5 \%\end{array}$ & $\begin{array}{c}27 \\
9.9 \%\end{array}$ & $\begin{array}{c}45 \\
16.5 \% \\
(.210)\end{array}$ & $\begin{array}{c}272 \\
100.0 \%\end{array}$ \\
\hline Total & $\begin{array}{c}2596 \\
78.9 \%\end{array}$ & $\begin{array}{c}329 \\
10.0 \%\end{array}$ & $\begin{array}{c}44 \\
1.3 \%\end{array}$ & $\begin{array}{c}225 \\
6.8 \%\end{array}$ & $\begin{array}{c}97 \\
2.9 \%\end{array}$ & $\begin{array}{c}3291 \\
100.0 \%\end{array}$ \\
\hline
\end{tabular}

integrated with the woman's household duties. We elaborate on this second point below.

First we discuss the basic consistency between the two work measures. 
All the women interviewed in the SFT survey were also interviewed in the 2003 DHS about 10 months earlier. Therefore, if the questions asked in the two surveys were equally effective at eliciting women's work status, we would expect virtually all of the respondents to fall on the diagonal in Table 2. That is, most of the women found to be not working at the time of the DHS would report themselves to be not working in the SFT survey; those working as professional/ technical/ clerical (PTC) workers in the DHS would be classified in the same category by the SFT; and so on.

Of course, over the period between the two surveys there would be some transition into and out of the work force, and between occupational categories. We can estimate the level of normal transitions by examining the PTC category in Table 2. 274 women report doing this sort of work in both surveys (Cell 2B in Table 2), a very high degree of consistent reporting. Twenty-two women who report having a PTC job in the DHS survey said, 10 months later at the time of the SFT survey, that they were not working. Similarly, 25 women who were found to be inactive at the time of the DHS survey reported having a PTC job in the SFT study. Using these numbers as a proxy for transition into and out of formal employment, we can estimate the level of these transitions at 7-8 percent of all workers in that occupational group, but at less than 1 percent of all women studied.

Other factors may also influence transitions into and out of work. For example, there are 15 women, who between the two surveys, appear to have moved from PTC work to agriculture/ animal husbandry. While at least some of this apparent shift may be error, even if these transitions are real, we do not believe that it reflects women who have left office jobs to work in the fields. Rather, it is possible that PTC women who were also raising a few chickens or a goat for home consumption at the time of the DHS study, had left their PTC job at the time of the SFT, but still persisted in their animal husbandry activities. If this is the case, the level of transition is higher than estimated above - as high as 17 percent of all PTC 
workers moved either out of the work force or between broad categories of work. But this is still less than 2 percent of all women.

These considerations, however, only pertain to women working in "formal" or "normative" jobs. We will see below that many apparent transitions from agriculture/ animal husbandry work in the DHS to sales or services/ manual jobs in the SFT are likely to result from women working at multiple tasks. Other transitions between broad job categories may result from women doing construction in the period before the DHS, and shifting to work in a seasonal harvest just before the SFT, or similar movements. Such work transitions are probably very common, and it is difficult, at best, to estimate the level of these transitions.

Finally, some apparent transitions are the result of error in one survey or the other. Nonetheless, even given these transitions, Table 2 reflects a substantial degree of consistency in reported work status in the two surveys. Just under half ( 49 percent) of all women interviewed fall on the diagonal; in other words they reported the same broad occupation at both time points.

The degree of consistency can be further assessed using the Kappa statistic. Kappa ranges between zero (0) and one (1). The overall Kappa for agreement between the two instruments is .247 , which is significant at the .001 level. It is also possible to assess agreement for each occupational group separately. The Kappas for each of the five categories are shown as the third number, in brackets, in the diagonal cells of Table 2. All of the Kappas in Table 2 are statistically significant (at the .001 level), thus demonstrating the essential consistency between the DHS and SFT reports of occupation. However, only the Kappa for the PTC workers, the most formal/ normative of the work categories, is very high (.844), reflecting a strong degree of consistency in reports of this type of work in the two surveys. All the other Kappas are below .210, with that for agriculture/animal husbandrywhich includes a very large proportion of women doing subsistence, very casual, very part- 
time work-being just .102. In sum, though the two reports of work status in the two surveys are statistically consistent, with the exception of the PTC group the level of consistency is modest.

At the same time, the degree of consistency between the two surveys in the reporting of work is somewhat greater than Table 2 indicates. Recall that in the SFT women can report more than one job. As it happens, among the 169 women who reported sales to be their main job in the SFT, 20 (12\% - cell 3D) reported that they had been working in agriculture/animal husbandry a year earlier at the time of the DHS, a larger number than reported working in sales in the earlier survey (17 women; $10 \%$ - cell $3 \mathrm{C})$. We noted above that these two forms of work often go together; for example, women who raise animals may sell products produced by those animals. And, indeed, all 20 women who fall in Cell 3D of Table 2 (DHS - agriculture/animal husbandry / SFT - sales) also reported in the SFT interview that they raise birds/animals, while 13 of them said they had worked in agriculture in addition to animal husbandry.

A similar result applies to the $27(10 \%$ - cell 5D) women who reported that their main work at the time of the SFT was service/manual labor but who in the DHS were found to work in agriculture/animal husbandry. Of these 27 women, 2 reported in the SFT that they raised birds/animals, 1 worked in agriculture, and the remaining 24 did both of these primary production jobs. Despite this, all declared that their main work was services/manual labor. In short, some apparent differences between the DHS and SFT reports are eliminated when all work reported in the SFT (main and secondary activities) is taken into account.

Despite this general consistency in the DHS and SFT data on women's work, there is striking change in the work data obtained by the SFT survey. This is our second key conclusion. The first evidence of this is the overall higher level of work found in the SFT data. As Table 2 shows, however, most of the changes in the respondents' work 
classification are due to women who were classified as not working in the DHS but who are found to be working by the SFT survey. The 2003 DHS reported a total of 2596 women who had not worked in the year before the survey, while in the SFT only 1106 (43 percent) of these women said they had done no work in the 3 months before being interviewed. The other 1490 women had worked in the 3 months prior to the SFT interview. Most of these women (1168 - cell 4A - or 78\% of the women who changed from not working to working between the two surveys) worked in agriculture and/or animal husbandry (with most, in fact,

raising animals or birds). However, substantial numbers also reported working in sales (113 cell 3A) and in service/manual jobs (184 - cell 5A). In all three of these categories (sales, agriculture/animal husbandry, and services/manual) a substantial proportion of all the women reported to be doing this work in the SFT had reported not working at the time of the DHS $(67 \%, 85 \%$, and $68 \%$, respectively). This is impressive evidence of the far greater coverage of women's economic activities in the SFT as compared to the DHS.

Inconsistent work reports, other than those in column A of Table 2 and in the two cells discussed above, are viewed primarily as error, though they may be evidence of work transitions, as discussed above. Under any circumstances, the number of women involved is small (a total of 146, just $4 \%$ of all women interviewed). They are scattered across a range of cells and follow no particular pattern.

\section{Nature of the Work Activities Captured by the Two Measures}

At the outset of our analysis, we assumed that the more casual, intermittent, part-time and home-based the work, the less likely that it would be reported in response to a keyword question about work, such as that included in the DHS instrument. The SFT activities list, on the other hand, captures non-normative economic activities, as well as PTC work which is 
more normative and likely to be reported in response to any question about work. This expectation can be tested empirically.

We can best evaluate the varying degree of success of the DHS and SFT in measuring normative versus non-normative work by examining, in detail, the women who reported they were doing service/manual labor in the SFT survey. The service/manual category includes women involved in many different types of work, ranging from tasks that are home-based, intermittent and closely related to household duties (making butter, ghee, cheese) to work that is more regular and normative, but that may still not be contractual, or come with social benefits (working in a factory or workshop). Only a few of the different tasks comprising this category contain sufficient women to support further examination. Among the jobs we can examine, however, are: 1) a casual, intermittent, home-based task-making butter, ghee, cheese; 2) a home-based task that may be contractual homework, or may be more casual and intermittent — sewing/embroidery; and 3) a job that is likely to be regular, and that may be contractual, and is almost certainly done outside the home-working in a factory or workshop. These are the only three specific tasks for which we have at least 10 workers available for this detailed analysis. We hypothesized that work that is more casual, intermittent and home-based is more likely to have been identified only in the SFT survey, while jobs that are more regular and normative are likely to have been reported in both the SFT and the DHS.

Our test involves assessing the likelihood that doing each of the three specific service/ manual tasks listed in the previous paragraphs, was identified in the SFT only or was reported in both surveys. In doing so, we focus on the 229 women in two cells (5A and 5E) of Table 2. Of these women, the 184 in Cell 5A were reported to be inactive in the DHS survey, but doing services/manual work in the SFT. That is, they were "newly identified" as services/manual workers in the SFT. The 45 women in Cell 5E, on the other hand, were 
identified as doing services/manual work in both surveys. To restate our hypothesis: women who do home-based, casual, intermittent tasks should fall disproportionately into cell 5A (SFT only), while those who do more regular, normative tasks will be more likely to be in cell 5E (both surveys).

For example, consider the analysis of women who make butter, ghee, or cheese, as shown in Table 3. A total of 91 women made butter, ghee, or cheese according to the SFT. Eighty-nine of these women are among the 184 women who were newly identified as doing this work in the SFT (cell 5A). Just two of the women who make butter, ghee, or cheese are among the 45 women who reported doing manual/services work in both surveys (cell 5E). That is, of the services/manual workers identified in the SFT only, fully $48 \%$ were making butter, ghee, or cheese. By contrast, among those who were doing services/manual work in both surveys, just 4\% made butter, ghee, or cheese. (See Table 3 below.) Thus, women who made butter, ghee, or cheese were strongly significantly more likely to be identified by the SFT only, than they were to be reported by both surveys. This is what we expect of a homebased, casual job such as making butter, ghee, or cheese.

Table 3. Test of Whether Production of Butter, Ghee or Cheese is an Informal (SFT Only), or Formal (Both Surveys) Task.

\begin{tabular}{|c|c|c|c|}
\hline & \multicolumn{4}{|c|}{ Make Butter, Ghee, or Cheese } \\
\cline { 2 - 4 } & Yes & No & Total \\
\hline SFT Only & 89 & 95 & 184 \\
(Cell 5A) & $(48.4 \%)$ & $(51.6 \%)$ & $(100.0 \%)$ \\
\hline Both Surveys & 2 & 43 & 45 \\
(Cell 5E) & $(4.4 \%)$ & $(95.6 \%)$ & $(100.0 \%)$ \\
\hline Total & 91 & 138 & 229 \\
& $(39.7 \%)$ & $(60.3 \%)$ & $(100.0 \%)$ \\
\hline
\end{tabular}

We can carry out a similar analysis for the two other services/manual tasks with more than 10 workers. In the case of women who do sewing/embroidery there is no significant difference in the likelihood of identifying these workers in both surveys, or in the SFT only. Among the 184 service/ manual workers who were newly identified in the SFT, 26.6 percent did sewing/ embroidery. This differs little from the 28.9 percent who do this work among the 
45 service/ manual workers identified in both the DHS and the SFT. Among the few service/ manual workers (11) who reported working in a factory or workshop there is a statistically significant greater tendency for this type of work to be reported in both surveys ( 6 of 45 ; $13.3 \%$ ) as compared to women who were reported to do this task in the SFT only; just 5 of $184(2.7 \%)$.

Among other specific service/ manual tasks with fewer than 10 women doing them, there is no relation between survey first identified and making sweets ( 8 cases), but a statistically-significant greater likelihood to be reported in both surveys for women who work in a hospital or clinic (5 cases), and for those who are housemaids ( 9 cases). We had expected sweet makers to be among the casual, intermittent workers more likely to be first identified in the SFT. Perhaps if we knew more about the way in which these women work, we would understand why they were as likely to report their work in the DHS. But, both maids/ housecleaners and particularly hospital/ clinic work are normative jobs, with the latter task likely to be formal and contractual. Thus the fact that they are disproportionately likely to be identified in both surveys conforms to our expectations.

Finally, we hypothesized that, on average, women first identified as working in the SFT (i.e. SFT only) would be more likely than women who reported working in both the DHS and SFT to be working part-time, and/or working without pay, two important characteristics of working on the family land or business, or on own-account, as many women who make butter, ghee, and cheese or who sell things in the souq are likely to do. We can assess this belief by comparing the characteristics of the jobs of newly identified women in each work category with those of the women who fall into the same category in both surveys. For example, we compare the characteristics of the 25 women newly identified by the SFT as PTC workers (cell 2A) with the 274 women reported doing PTC work in both 
surveys (cell 2B), those newly identified as sales workers (cell 3A) with those determined to be sales workers in both the DHS and SFT (cell 3C), and so forth.

Looking at each broad occupational category individually, only newly identified services/manual workers are significantly more likely to be working without pay than are services/manual workers identified in both surveys. Considering hours worked per week outside the home, however, women first found to be economically active in the SFT worked fewer hours per week on average than did women who reported doing the same type of work in both surveys. This effect is statistically significant for all four broad occupational categories. Among women working in PTC and non-subsistence primary production jobs, these differences in hours worked, although statistically significant, are modest (newly identified women worked, on average, 3-4 fewer hours per week). Among those working in sales and services/manual labor, on the other hand, the women newly identified in the SFT worked 18-19 fewer hours outside the home each week than women who did this type of work in both surveys. This suggests that those newly identified in the SFT are more likely to be working part-time, especially those women who do sales and service/manual work. (See Appendix B, Table 1.)

This pattern is clearer when we compare all newly identified workers with all those who report being economically active in both surveys. This overall comparison confirms that newly identified workers work significantly fewer hours than those who are classified by both the DHS and the SFT as working, even when we exclude those who work for subsistence. Newly identified workers, on average, spend 19 hour per week outside the home, as opposed to an average of 33 hours for those who reported working in both surveys. Moreover, women newly identified as workers in the SFT survey are, overall, significantly more likely to work without pay than are those found to be working in both surveys. Just 65 percent of newly identified workers were remunerated for their work, compared to 87 percent 
of those workers captured by both surveys. These figures exclude those working for subsistence only, since they, by definition, receive no pay for their work.

All of these differences suggest that the SFT-identified work is more casual and intermittent than work found in both surveys.

\section{Background Characteristics of Working Women Captured by the Two Measures}

Workers newly identified in the SFT differ from workers recorded in both surveys not only on the types of work they do but also in terms of their background characteristics. No clear pattern emerges when working women are disaggregated by occupational category. (Data not shown.) However, if we compare all those newly identified as economically active by the SFT with those who reported working in both surveys, we find that, overall, the newly identified workers are significantly: 1) less educated; 2) poorer; and 3) younger than were the women who were reported to be working in both surveys. (See Figure 3.) In comparison to women classified as not working in both surveys, newly identified workers are also significantly 1) less educated; 2) poorer; and 3) older. As a consequence, when the SFT

Figure 3. Background Characteristics of Workers Newly Identified in the SFT, Compared with Those Reported: 1) Not Working and 2) Working in Both Surveys.

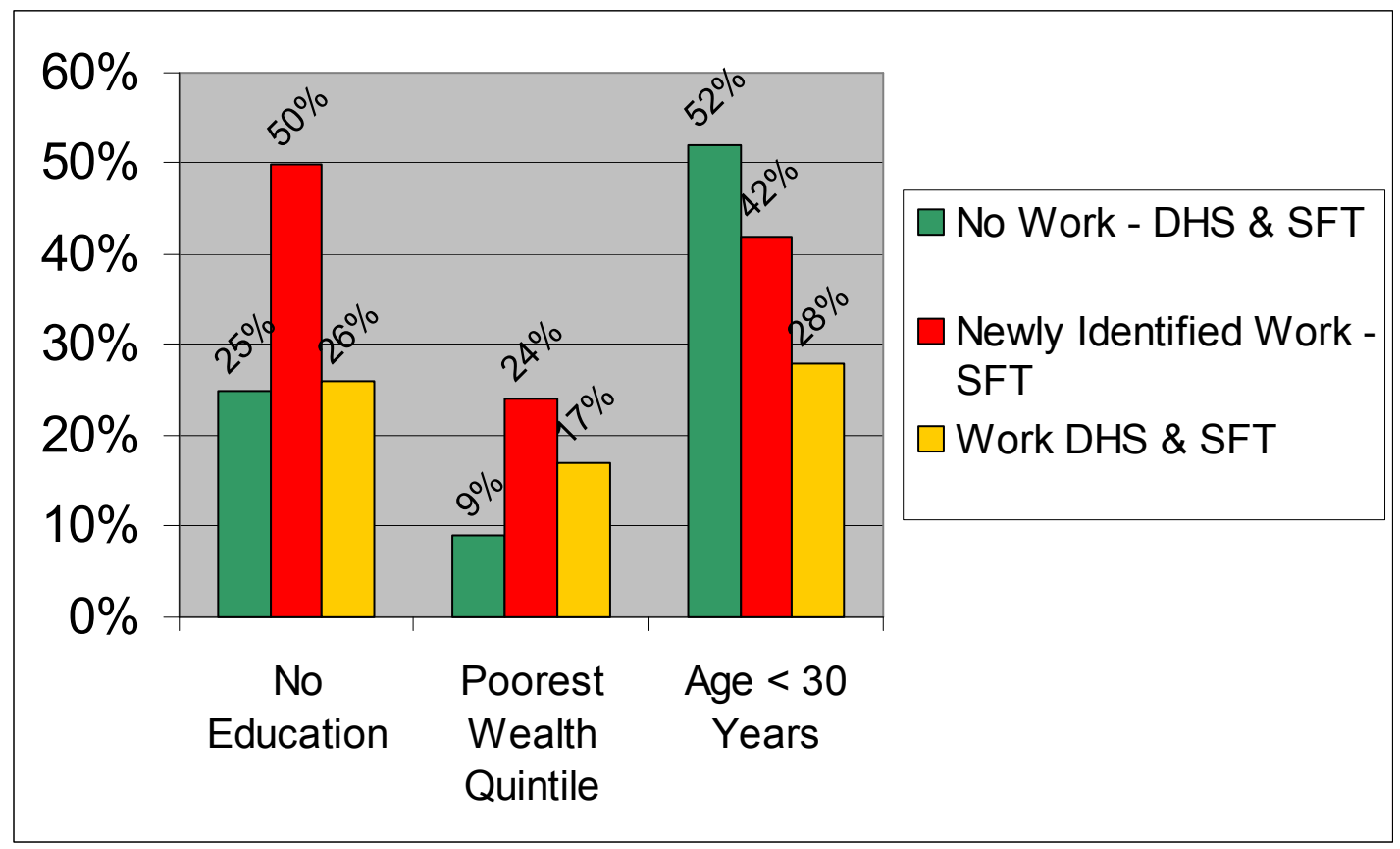


shifts women who were erroneously classified as not working by the DHS out of the inactive category, the average educational levels and household economic status of women who were not working in the SFT, increases as compared to non-workers in the DHS.

\section{Comparison of the SFT and ELMS 1998 Work Measures}

We have shown that the SFT activities list format is substantially more effective at identifying women workers than is the single keyword question used in the DHS. But, Anker has suggested that either a detailed activities list, or several detailed keyword questions is an effective means of collecting data on women's economic activities (Anker and Anker 1989). The 1998 ELMS survey followed the latter approach. The employment module of the ELMS begins with a general keyword question asking about "participation in any work". If the respondent answered "no", she was asked a series of eight additional keyword questions focusing on such issues as "producing goods that are sold", "offering paid services to others", "buying goods and reselling them", "independent paid work, "helping in the family business", "participation in an agricultural project", "learning a skill in a factory or workshop". Finally there is a question asking about "participation in subsistence agriculture or animal husbandry". Table 4 compares reported women's economic activity for the ELMS and the SFT.

First, note that the women's economic activity is 40 percent higher in the SFT (64 percent of women working) as compared to the ELMS (46 percent working). But, the comparison by broad occupation groups is particularly telling. The ELMS actually finds a higher percentage of women working in the normative, more formal PTC category. And the SFT finds only about 35 percent more women working in subsistence agriculture/ animal husbandry. However, in the case of sales jobs, service work/ manual production, and 
Table 4. Reported Work in ELMS 1998 and SFT 2004 by Broad Occupational Category Ever-Married Women, 15-49 Years of Age.

\begin{tabular}{|r|c|c|}
\hline & ELMS-1998 & SFT-2004 \\
\hline Sales & $2.4 \%$ & $5.1 \%$ \\
\hline Service/ Manual & $1.8 \%$ & $8.3 \%$ \\
\hline Primary Prod - Subsistence & $24.9 \%$ & $33.7 \%$ \\
\hline Primary Prod - Wage/ Market & $1.7 \%$ & $8.1 \%$ \\
\hline \hline Total Working & $46.0 \%$ & $64.5 \%$ \\
\hline \hline $\mathrm{N}$ & 3849 & 3293 \\
\hline
\end{tabular}

agriculture/ animal husbandry for a wage or for the market, the percentages of women workers identified by the SFT activities list is two, to almost four, times greater than the percent of workers identified by the detailed ELMS keyword questions. These occupational categories are those where most of the casual, intermittent, part-time, home-based jobs are likely to be found. Indeed, in the ELMS virtually all the workers not identified by the first broad keyword question were found to be doing subsistence agriculture. A total of just 6 women (only 0.2 percent of all ever-married women 15-49 years of age) gave a positive response to any of the 8 supplemental keyword questions ${ }^{8}$.

The implication of this analysis is that additional keyword questions make little or no contribution to the level of women's work identified. The single activity question on subsistence agriculture used in the ELMS was, however, helpful in identifying more women

\footnotetext{
${ }^{8}$ The1998 ELMS supplemental keyword questions may have been more effective at identifying workers than this result suggests. According to its Principal Investigator, in practice when the interviewers identified a worker using the supplemental questions, they corrected the response to the initial, general keyword question, inserting the worker there. Regardless of the discrepancy between the questionnaire's instructions and actual practices in the field, the jobs that these supplemental keyword questions are meant to identify (production of butter or cheese for sale, selling in the souq or in a family shop, work in a factory or workshop) are the very jobs that remain under-reported in the ELMS.
} 
workers. In sum, the SFT activities list not only outperforms a single keyword question such as is used in the DHS, it also is more effective in identifying women workers than are multiple detailed keyword questions.

\section{$\underline{\text { Discussion }}$}

In assessing different approaches to measuring women's work, we have followed the pioneering work of Anker and his colleagues (Anker, Khan and Gupta 1987; Anker and Anker 1989; Anker 1990; Anker and Anker 1995). Consistent with Anker's findings, we have shown that an activities list more accurately identifies working women than do keyword questions. Unfortunately, Anker's work has been largely ignored and forgotten. Though the 1988 LFSS and 1998 ELMS questionnaires in Egypt appear to have been influenced by the 1984 Egypt methods test, these surveys used multiple keyword questions, rather than an activities list. Anker has written that it is "not very important" whether information on specific women's labor force activities is gathered "through the use of a sufficiently long set of key-word questions or through the use of an activity schedule" (Anker and Anker 1989: 519). On this point we reach a different conclusion. Comparison of the results of the 1998 ELMS and the 2003 SFT, above, shows that the eight detailed ELMS keyword probes identified very few women workers, and resulted in substantial under-reporting of work in several key occupational categories. An activities list is required to fully account for women's work.

Moreover, the activities list has other important advantages: 1) "no a priori assumptions are made about what is, and what is not, a labour force activity"; 2) "labour force participation can be defined after the survey has been completed—in different ways for different purposes and definitions"; and 3) all jobs that a woman performs are identified, thus indicating "how fully individuals are integrated into the economy" (Anker 1983: 517). To 
these advantages, we add one more: activities questions are easy; keyword questions are hard.

To begin with the last point: the activities questions used in the SFT survey were short and easy for interviewers to ask. Though the activities list includes a large number of questions (18 were used in the SFT questionnaire), each question is brief and clear to the respondents, who must simply give a yes or no answer. Keyword questions, on the other hand, are often lengthy, and the terms used may be ambiguous, or even "socially loaded", to many respondents (Anker 1983). When the interviewer asks whether a respondent has a "job" or is "currently working", the time she spends caring for goats, and making cheese that her husband sells in the market may not even come to mind; such tasks may be alien to her normative view of jobs and work. It is widely recognized that, when using keyword questions, interviewers must use "special probes" or "detailed prompts" to help respondents “think about and report ... activities that they might not ordinarily consider 'work' or "employment"” (Schaffner 2000a: 238; Hussmanns n.d.). But, the lower rates of labor force participation reported in the LFSSes of 1990 and 1995 (Figure 1), and seen also in the DHSes of 1995 and 2000 (Figure 2)—declines attributed to "waning effort" to carefully probe women's work (Assaad and El-Hamidi 2001; Assaad 2002) — testify to the difficulty of maintaining a high level of detailed probing. The activities list, on the other hand, makes these special probes and prompts explicit. If the respondent is asked whether she raises poultry or livestock; or whether she makes butter, cheese, or ghee to sell, no probing is required: she can readily answer yes or no.

Anker's work has been criticized because of the high level of women's labor force participation reported (Basu 1989). It is certainly the case that inclusion of household tasks in the definition of labor force activity — use value production (Beneria 1982) — will often result in "virtually all able-bodied women ... [being] economically active" (Dixon 1982:542). 
But, these are criticisms of the definition of labor force participation. We (and AnkerAnker, Khan and Gupta 1987) are not concerned with the definition of the labor force, nor is it our objective to prove that a high percentage of women are working. Rather, we are testing the effects of the approach used to collect data on the percent of women economically active, assuming a consistent definition of who should be considered a member of the labor force. We believe that the DHS, the 1998 ELMS, and the SFT all use essentially the same definition of the labor force. Thus, the much higher level of labor force participation found in the SFT is the result of using an instrument that more accurately measures work.

As Anker points out, an activities list "makes no a priori assumptions about what is, and what is not, a labour force activity"; indeed, when using an activities list, "labour force participation can be defined after the survey has been completed" (Anker 1983: 717). This is because the activities list can include questions about tasks that may or may not fit the definition of "labor force activity" ultimately used. For example, in his activities list Anker includes questions about some domestic activities such as gathering wood/fuel, making dung cakes, and fetching water (Anker, Khan, and Gupta 1987). Since each of these tasks enters the data set as a discrete, explicit variable, whether to include these tasks in the definition of the labor force can be decided at any time. Other criteria can also be imposed on each task or job when deciding whether or not it should be included as a labor force activity. For example, workers may be required to work a minimum number of hours per week, or to earn a wage or make a product to sell, in order to be considered economically active (Anker, Khan and Gupta 1987). But it is necessary to identify potential workers before they can be queried about the hours they work and the money they may or may not receive. Although the workers newly identified by the SFT activities list work fewer hours and are less likely to be remunerated than workers captured in both the DHS and SFT studies, it remains the case that the newly identified workers spend, on average, 19 hours per week working outside the 
home, and 65 percent of them earn money from the work they do. Thus many of the workers missed by the DHS make a meaningful economic contribution - to their families and to the national accounts.

Finally, the activities list provides an easy means of identifying all the jobs a woman has performed during the reference period. Other observers have noted that women in developing countries commonly are involved in multiple activities (Anker, Khan and Gupta 1987; Schaffner 2000a). When many activities are performed they can be added together to assess the woman's actual degree of participation in the economy (Anker 1983). But the DHS format provides no scope for recording more than one job, and the ELMS structure is less effective at identifying those who do multiple tasks.

The activities list requires a relatively large number of questions. We have already mentioned that the questions are easy to answer, and take very little additional time to complete. Nevertheless, it could be that in a survey such as the DHS, where women's work is not a main focus, the long list of activities may be viewed as an undue burden. In this case, those using women's work in their analyses should be aware that most working women have not been identified, and that the identified workers have characteristics different from the workers left uncaptured by the single keyword question used in the DHS. But, even in questionnaires like the sample modules for the Living Standards Measurement Study (LSMS), just 3 questions are used to identify workers. There are no LSMS data for Egypt that we can assess. But, we assume that the two keyword questions focused on identifying: 1) wage workers; and 2) own account workers, supplemented by a question about subsistence agriculture, will be no more, and probably less, effective at identifying casual, intermittent, part-time workers than even the more detailed ELMS keyword questions. And the LSMS does not face the same constraints of number of questions encountered by the DHS. The standard version of the LSMS employment module asks more than 100 questions about work 
in the last 7 days (Schaffner 2000b). In such a lengthy module the activities list would scarcely be noticed, but would probably significantly improve the reporting of women's work

We have already noted the need to measure women's labor force activity for diagnosing the causes of poverty and inequality, and the prominence of women's work as an explanatory factor in theories related to reproductive change, child welfare, and economic development, among others. Commonly observed relationships between women's work and these various outcomes may well be overturned or revised were they to be tested using a more complete measure of work as provided by the activities list. Assessment of these issues is beyond the scope of this paper.

We do, however, wish to emphasize one area where the activities list can have a very direct impact on the understanding of an important issue - the study of the "informalization" of the labor force. Interest in the informal sector prompted the International Conference of Labour Statisticians to issue a resolution defining the sector in 1993 (ILO 1993). In the last decade there have been numerous studies examining the growth and impact of employment in the informal sector in all parts of the world (ILO n.d.; Charmes 1998; Bajaj 1999; Chen, Sebstad and O’Connell 1999; Mehra and Gammage 1999; Standing 1999; Carr, Chen, and Tate 2000; Chen 2001; Carr and Chen 2002; Muller 2002; Chen 2004; Avirgan, Bivens, and Gammage 2005). There have also been a number of studies of informalization in Egypt, using data from the 1998 ELMS (Wahba 2000; Assaad 2002; El-Mahdi 2002a; El-Mahdi 2002b; Moktar and Wahba 2002).

Although historically the informal sector has often been thought of as an urban phenomenon, in fact, informal work is prevalent in agriculture, food production, petty commerce, construction, and other jobs performed by women in rural, as well as urban, areas (Chen and Vanek 2005; see also ILO n.d.; ILO 2002). "Many developing countries have a 
'traditional' informal sector of traders, artisans, and service groups" (Chen, Sebstad, and O'Connell 1999: 609). Indeed, that is what we see in the SFT data with a large number of women workers making butter, ghee, or cheese; sewing and embroidering; selling in the souq or from home shops; working as maids or housecleaners. But, all the articles on informalization in Egypt focus on the "market" or the "paid" labor force (Assaad 2002) or on nonagricultural wageworkers (El-Mahdi 2002b). This is a correct decision in this caseimposed by constraints of the data available. As we have shown above, it is precisely traditional informal workers that were disproportionately missed by the keyword questions used in the ELMS.

To fully assess the impact of structural adjustment and other economic changes on women in the informal sector (as formally defined) it will be necessary to use an activities list to capture all the women who do casual, intermittent, part-time, home-based - that is, informal work in Egypt.

\section{Conclusions}

In this paper, we assess two approaches to measuring women's work in Egypt, examining two sets of responses from the same sample of ever-married women, obtained in the DHS 2003 and the SFT 2004 surveys. DHS uses a standard keyword question; the activities list approach was used in the SFT.

From this comparison, it is clear that a single keyword question fails to measure the full range of economic activities in which Egyptian women are engaged. The proportion of women classified as working in the DHS is only one-third of the proportion working according to the SFT. Our analysis further suggests that there are important differences in the type of work activities captured by both surveys. Our expectation that women newly identified as working by the SFT are more likely to be engaged in casual, intermittent, part- 
time, unremunerated, in general, more informal, work is borne out by the data. Moreover, the newly captured working women are disadvantaged in terms of their educational and socioeconomic background as compared to women classified as working in the DHS.

We also show that the SFT activities list captured more working women than even the multiple keyword questions used in the ELMS. While the ELMS identified a greater share of working women than did the DHS, the main advantage of the ELMS was in the area of subsistence agriculture, most likely because the ELMS included a direct activity question about this type of work.

The questions asked in the SFT conform to a definition of work that is essentially the same as that employed by surveys such as the DHS and ELMS. Thus, the additional working women identified result from the use of a measurement technique that captures the full range of women's productive experiences meant to be included under a widely accepted conceptualization of work. At the same time, the activities list approach is flexible, and able to accommodate any definition of work, including use value production. The detailed nature of the questions allows for different definitions to be tested - even after collection of the data.

The activities list used in this work was experimental. Future work testing approaches that combine a keyword question, followed by an activities list, is required. For example, to preserve the comparability of results over time, DHS questionnaires could retain the keyword question they currently use. This question would be supplemented by an appropriate activities list to capture the many working woman the sole keyword question misses. There may also be a need to improve the structure of the activities list to avoid asking inappropriate questions and to properly introduce potentially sensitive questions. Examples showing how activities lists could be integrated into the DHS, ELMS, and LSMS questionnaires are in Appendix C. 
While we have focused in this research on the labor force participation of women, we believe that the activities list would also be the most effective way of measuring children's work. We originally developed an activities list for a questionnaire that was used with adolescent girls in rural Egypt. Much of the work of children in developing countries shares the casual, intermittent, part-time characteristics of the newly identified women workers found in the SFT study. Research should be conducted to test the use of activities lists with children.

Despite the need for further research, the activities list approach has already been shown to yield analytical benefits while remaining easy to use during data collection in the field. A detailed list of economic activities such as that employed in the SFT may take only a few minutes longer to administer than the usual DHS format. The additional questions would hardly be noticed in an extensive labor force survey such as the ELMS or the LSMS. Training interviewers to use the activities list is also straightforward, since the questions are clear and direct, with little or no probing required. With the replacement or supplementation of current keyword work questions by the activities list approach, survey instruments such as the one used by the DHS could collect data that would better represent the full range of economic activities performed by Egyptian women, thereby improving our knowledge and understanding of women's productive contributions and how these contributions affect other domains of life. 


\section{BIBLIOGRAPHY}

Anker, Richard. 1983. "Female Labour Force Participation in Developing Countries: A Critique of Current Definitions and Data Collection Methods." International Labour Review 122:709-723.

Anker, Richard. 1990. "Methodological Considerations in Measuring Women's Labor Force Activity in Developing Countries: The Case of Egypt." Pp. 27-58 in Research in Human Capital and Development, vol. 6, edited by I. Sirageldin. Greenwich, Conn: Jai Press.

Anker, Richard and Martha Anker. 1989. "Measuring the Female Labour Force in Egypt." International Labour Review 128:511-526.

Anker, Richard and Martha Anker. 1995. "Measuring Female Labour Force with Emphasis on Egypt." Pp. 148-176 in Gender and Development in the Arab World, edited by N. F. Khoury and V. M. Moghadam. London: Zed Books.

Anker, Richard, M.E. Khan, and R.B. Gupta. 1987. "Biases in Measuring the Labour Force: Results of a methods test survey in Uttar Pradesh, India." International Labour Review 126:151-167.

Assaad, Ragui. 1997. "The Employment Crisis in Egypt: Current Trends and Future Prospects." Pp. 39-66 in Research in Middle East Economics, vol. 2, edited by K. Pfeifer. Greenwich, Conn: Jai Press.

Assaad, Ragui. 2002. "Informalization and De-feminization: Explaining the unusual pattern in Egypt." Pp. 20 in Rethinking Labor Market Informalization: Precarious Jobs, Poverty, and Social Protection. Ithaca, NY.

Assaad, Ragui. 2002. "The Transformation of the Egyptian Labor Market: 1988-98." Pp. 364 in The Egyptian Labor Market in an Era of Reform, edited by R. Assaad. Cairo: The American University in Cairo Press.

Assaad, Ragui and Fatma El-Hamidi. 2001. "Is All Work the Same? A Comparison of the Determinants of Female Participation and Hours of Work in Various Employment States in Egypt." Pp. 117-150 in The Economics of Women and Work in the Middle East and North Africa, vol. 4, edited by M. Cinar. Greenwich, Conn.: Jai Press.

Bajaj, Manjul. 1999. "Invisible Workers, Visible Contribution: A Study of Homebased Women Workers in Five Sectors across South Asia." WIEGO, Cambridge, MA.

Basu, Alaka M. 1989. "Book Review: Women's Participation in the Labour Force: A Methods Test in India for Improving its Measurement." Population Studies 43:515-516.

Beneria, Lourdes. 1981. "Conceptualizing the Labor Force: The Underestimation of Women's Economic Activities.” The Journal of Development Studies 17:10-28. 
Beneria, Lourdes. 1982. "Accounting for Women's Work.” Pp. 119-147 in Women and Development: The Sexual Division of Labor in Rural Societies, edited by L. Beneria. New York: Praeger.

Beneria, Lourdes. 1992. "Accounting for Women's Work: The Progress of Two Decades." World Development 20:1547-1560.

Boserup, Ester. 1970. Woman's Role in Economic Development. New York: St. Martin's Press.

Carr, Marilyn and Martha Alter Chen. 2002. "Globalization and the Informal Economy: How Global Trade and Investment Impact on the Working Poor." International Labour Office, Geneva.

Carr, Marilyn, Martha Alter Chen, and Jane Tate. 2000. "Globalization and Home-Based Workers." Feminist Economics 6:123-142.

Charmes, Jacques. 1998. "Women Working in the Informal Sector in Africa: New Methods and New Data." Scientific Research Institute for Development and Co-operation, Paris.

Chen, Martha Alter. 2001. "Women in the Informal Sector: A Global Picture, the Global Movement." SAIS Review 21:71-82.

Chen, Martha. 2004. "Rethinking the Informal Economy: Linkages with the Formal Economy and the Formal Regulatory Environment." Expert Group on Development Issues, Helsinki.

Chen, Martha, Jennefer Sebstad, and Lesley O'Connell. 1999. "Counting the Invisible Workforce: The Case of Homebased Workers.” World Development 27:603-610.

Chen, Martha and Joann Vanek. 2005. "Informal Employment: Rethinking Workforce Development." Pp. 491-502 in Good Jobs, Bad Jobs, No Jobs: Labor Markets and Informal Work in Egypt, El Salvador, India, Russia, and South Africa, edited by T. Avirgan, L. J. Bivens, and S. Gammage. Washington, DC: Economic Policy Institute.

Dixon, Ruth. 1982. "Women in Agriculture: Counting the Labor Force in Developing Countries." Population and Development Review 8:539-566.

Donahoe, Debra Anne. 1999. "Measuring Women's Work in Developing Countries." Population and Development Review 25:543-576.

El-Mahdi, Alia. 2002a. "Towards Decent Work in the Informal Sector: The case of Egypt." International Labour Office, Geneva.

El-Mahdi, Alia. 2002b. "The Labor Absorption Capacity of the Informal Sector in Egypt." Pp. 99-130 in The Egyptian Labor Market in an Era of Reform, edited by R. Assaad. Cairo: The American University in Cairo Press.

Fergany, Nader. 1990. "Design, Implementation and Appraisal of the October 1988 Round of the LFSS." CAPMAS, Cairo. 
Hussmanns, Ralf. n.d. "Defining and Measuring Informal Employment.” International Labour Office, Geneva.

ILO. 1982. "Resolution concerning statistics of the economically active population, employment, unemployment and underemployment, adopted by the Thirteenth International Conference of Labour Statisticians."

(http://www.ilo.org/public/english/bureau/stat/res/infsec.htm)

ILO. 1993. Resolution Concerning Statistics of Employment in the Informal Sector adopted by the $15^{\text {th }}$ International Conference of Labor Statisticians. (http://www.ilo.org/public/english/bureau/stat/res/infsec.htm)

ILO. n.d. "Skills Development for the Informal Economy.” Pp. 5 , vol. 2006. Geneva: International Labour Office.

Kabeer, Naila. 1997. "Women, Wages and Intra-household Power Relations in Urban Bangladesh." Development and Change 28:261-302.

Leila, Reem. 2001. "Anything but a breeze.” in Al-Ahram Weekly. Cairo.

Mehra, Rekha and Sarah Gammage. 1999. "Trends, Countertrends, and Gaps in Women's Employment." World Development 27:533-550.

Moktar, May and Jackline Wahba. 2002. "Informalization of Labor in Egypt.” Pp. 131-157 in The Egyptian Labor Market in an Era of Reform, edited by R. Assaad. Cairo: The American University in Cairo Press.

Muller, Colette. 2002. "Measuring South Africa's Informal Sector: An Analysis of National Household Surveys." University of Natal, Durban.

Papps, Ivy. 1992. "Women, Work and Well-Being in the Middle East: An Outline of the Relevant Literature." The Journal of Development Studies 28:595-615.

Recchini de Lattes, Zulma and Catalina H. Wainerman. 1986. "Unreliable Account of Women's Work: Evidence from Latin American Census Statistics." Signs" Journal of Women in Culture and Society 11:740-750.

Salway, Sarah, Shahana Rahman, and Sonia Jesmin. 2003. "A Profile of Women's Work Participation Among the Urban Poor of Dhaka.” World Development 31:881-901.

Schaffner, Julie Anderson. 2000a. "Employment." Pp. 217-250 in Designing Household Survey Questionnaires for Developing Countries: Lessons from 15 Years of the Living Standards Measurement Study, vol. 1, edited by M. Grosh and P. Glewwe. Oxford: The World Bank.

Schaffner, Julie Anderson. 2000b. "Module for Chapter 9 - Employment." Pp. 147-217 in Designing Household Survey Questionnaires for Developing Countries: Lessons from 
15 Years of the Living Standards Measurement Study, vol. 3, edited by M. Grosh and P. Glewwe. Oxford: The World Bank.

Standing, Guy. 1999. "Global Feminization Through Flexible Labor" A Theme Revisited." World Development 27:583-602.

Wahba, Jackline. 2000. "Formal Testing of Informalization of Labor in Egypt: Has Informalization Increased in Egypt?” University of Southampton, Southampton. 


\section{$\underline{\text { Appendices }}$}

Appendix A. The SFT activities list.

"In the last 3 months, have you done any of the following activities..."

Done anything in the fields such as harvesting, cutting clover or watering plants?

Raised poultry or livestock?

Sewing or embroidery at home to sell?

Made sweets, koshari, tamaia, feteer at home to sell?

Prepared vegetables at home to sell?

Made butter, ghee, cheese at home to sell?

Anything else at home to sell?

Worked in an office or school?

Worked in a hospital or clinic?

Worked in a bank?

Worked in a government office or in the public sector?

Worked in a restaurant or hotel?

Worked in a factory or workshop?

Sold something in the market or a shop?

Sold something from home?

Did construction work, such as carried cement, bricks or sand?

Worked in someone else's home?

Did anything else similar? 


\section{Appendix B.}

Table B1. Percent Working Without Pay and Means Hours Worked Outside the House Among Those Who Reported Having No Work in DHS but Who Were Working in SFT (designated "Newly identified SFT"), in Comparison with Those who were Reported having the Same Work in Both DHS and SFT.

\begin{tabular}{|c|c|c|c|c|c|c|}
\hline & \multicolumn{3}{|c|}{ Work Without Pay } & \multicolumn{3}{|c|}{ Mean Hours Worked } \\
\hline & $\begin{array}{l}\text { Newly } \\
\text { Identified } \\
\text { in SFT }\end{array}$ & $\begin{array}{l}\text { Worked in } \\
\text { Both DHS } \\
\text { \& SFT }\end{array}$ & $\begin{array}{l}\text { Level } \\
\text { of } \\
\text { Signif. }\end{array}$ & $\begin{array}{l}\text { Newly } \\
\text { Identified }\end{array}$ & $\begin{array}{c}\text { Worked } \\
\text { in Both } \\
\text { DHS \& } \\
\text { SFT }\end{array}$ & $\begin{array}{l}\text { Level } \\
\text { of } \\
\text { Signif. }\end{array}$ \\
\hline $\begin{array}{l}\text { Professional/ } \\
\text { Technical/ Clerical }\end{array}$ & $\begin{array}{c}0.0 \% \\
(25)\end{array}$ & $\begin{array}{l}0.0 \% \\
(274) \\
\end{array}$ & NS & $\begin{array}{l}33.7 \\
(25)\end{array}$ & $\begin{array}{l}37.4 \\
(274)\end{array}$ & $<.05$ \\
\hline Sales & $\begin{array}{l}35.4 \% \\
(113)\end{array}$ & $\begin{array}{c}29.4 \% \\
(17) \\
\end{array}$ & NS & $\begin{array}{l}26.0 \\
(113) \\
\end{array}$ & $\begin{array}{l}44.5 \\
(17)\end{array}$ & $<.01$ \\
\hline $\begin{array}{l}\text { Agriculture/Animal } \\
\text { Husbandry } \\
\text { (excluding } \\
\text { Subsistence) }\end{array}$ & $\begin{array}{l}57.0 \% \\
(158)\end{array}$ & $\begin{array}{c}47.7 \% \\
(88)\end{array}$ & NS & $\begin{array}{l}23.2 \\
(158)\end{array}$ & $\begin{array}{l}27.8 \\
(88)\end{array}$ & $<.05$ \\
\hline Services/Manual & $\begin{array}{l}21.1 \% \\
(180)\end{array}$ & $\begin{array}{c}2.3 \% \\
(44)\end{array}$ & $<.01$ & $\begin{array}{c}9.6 \\
(180)\end{array}$ & $\begin{array}{l}28.8 \\
(45)\end{array}$ & $<.01$ \\
\hline
\end{tabular}




\section{Appendix C}

Below are some examples of how questionnaires could be adapted to include activities lists.

\section{DHS}

We begin with the DHS questionnaire. An example of the questions used in 2003 is below.

\begin{tabular}{|c|c|c|}
\hline 920 & $\begin{array}{l}\text { Now I would like to ask you some } \\
\text { questions about working. As you } \\
\text { know, some women take up jobs for } \\
\text { which they are paid in cash or kind. } \\
\text { Others sell things, have a small } \\
\text { business or work on the family farm, } \\
\text { or in the family business. Before } \\
\text { you married for the first time, did } \\
\text { you do any of these things or any } \\
\text { work? }\end{array}$ & 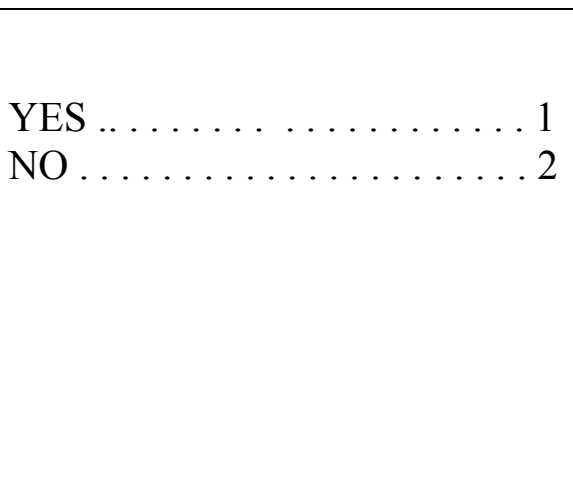 \\
\hline 921 & $\begin{array}{l}\text { Are you currently doing any of these } \\
\text { things or any other work? }\end{array}$ & $\begin{array}{l}\text { YES } \ldots \ldots \ldots \ldots \ldots \ldots \ldots \ldots{ }^{1} \\
\text { NO } \ldots \ldots \ldots \ldots \ldots \ldots \ldots 2\end{array}$ \\
\hline 1000 & $\begin{array}{l}\text { Have you done any work in the last } \\
12 \text { months? }\end{array}$ & $\begin{array}{l}\text { YES } \ldots \ldots \ldots \ldots \ldots \ldots \ldots 1 \\
\text { NO } \ldots \ldots \ldots \ldots \ldots \ldots \ldots 2\end{array}$ \\
\hline
\end{tabular}

To maintain as much comparability as possible, we retain questions 920 and 921 just as they are in the normal DHS questionnaire. We adjust question 1000 to provide an introduction to the activities list. And then we just add the activities list following question 1000.

\begin{tabular}{|c|c|c|}
\hline 920 & $\begin{array}{l}\text { Now I would like to ask you some } \\
\text { questions about working. As you } \\
\text { know, some women take up jobs for } \\
\text { which they are paid in cash or kind. } \\
\text { Others sell things, have a small } \\
\text { business or work on the family farm, } \\
\text { or in the family business. Before } \\
\text { you married for the first time, did } \\
\text { you do any of these things or any } \\
\text { work? }\end{array}$ & $\begin{array}{l}\text { YES } \ldots \ldots \ldots \ldots \ldots \ldots \ldots 1 \\
\text { NO } \ldots \ldots \ldots \ldots \ldots \ldots 2\end{array}$ \\
\hline 921 & $\begin{array}{l}\text { Are you currently doing any of these } \\
\text { things or any other work? }\end{array}$ & 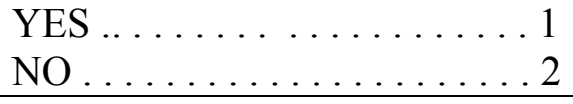 \\
\hline 1000 & $\begin{array}{l}\text { Just to be sure: in the last } 12 \text { months } \\
\text { have you done any of the following } \\
\text { activities: }\end{array}$ & \\
\hline
\end{tabular}




\begin{tabular}{|c|c|c|}
\hline 1010 & $\begin{array}{l}\text { Done anything in the fields such as } \\
\text { harvesting, cutting clover or } \\
\text { watering plants? }\end{array}$ & $\begin{array}{l}\text { YES } \ldots \ldots \ldots \ldots \ldots \ldots \ldots \ldots \ldots \ldots \\
\text { NO } \ldots \ldots \ldots \ldots \ldots \ldots \ldots 2\end{array}$ \\
\hline 1020 & Raised poultry or livestock? & $\begin{array}{l}\text { YES } \ldots \ldots \ldots \ldots \ldots \ldots \ldots{ }^{1} \\
\text { NO } \ldots \ldots \ldots \ldots \ldots \ldots \ldots 2\end{array}$ \\
\hline 11110 & $\begin{array}{l}\text { Sewing or embroidery at home to } \\
\text { sell? }\end{array}$ & 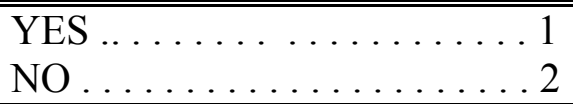 \\
\hline 1120 & $\begin{array}{l}\text { Made sweets, koshari, tamaia, feteer } \\
\text { at home to sell? }\end{array}$ & $\begin{array}{l}\text { YES } \ldots \ldots \ldots \ldots \ldots \ldots{ }^{1} \\
\operatorname{NO} \ldots \ldots \ldots \ldots \ldots \ldots \ldots 2\end{array}$ \\
\hline 1130 & Prepared vegetables at home to sell? & $\begin{array}{l}\text { YES } \ldots \ldots \ldots \ldots \ldots \ldots \ldots \ldots \ldots \ldots \\
\text { NO } \ldots \ldots \ldots \ldots \ldots \ldots \ldots 2\end{array}$ \\
\hline 1140 & $\begin{array}{l}\text { Made butter, ghee, cheese at home } \\
\text { to sell? }\end{array}$ & $\begin{array}{l}\text { YES } \ldots \ldots \ldots \ldots \ldots \ldots \ldots{ }^{1} \\
\text { NO } \ldots \ldots \ldots \ldots \ldots \ldots \ldots 2\end{array}$ \\
\hline 1150 & Anything else at home to sell? & $\begin{array}{l}\text { YES } \ldots \ldots \ldots \ldots \ldots \ldots \ldots{ }^{1} \\
\text { NO } \ldots \ldots \ldots \ldots \ldots \ldots 2 \\
\end{array}$ \\
\hline 1210 & Worked in an office or school? & $\begin{array}{l}\text { YES } \ldots \ldots \ldots \ldots \ldots \ldots \ldots{ }^{1} \\
\operatorname{NO} \ldots \ldots \ldots \ldots \ldots \ldots \ldots 2\end{array}$ \\
\hline 1220 & Worked in a hospital or clinic? & $\begin{array}{l}\text { YES } \ldots \ldots \ldots \ldots \ldots \ldots \ldots{ }^{1} \\
\text { NO } \ldots \ldots \ldots \ldots \ldots \ldots 2\end{array}$ \\
\hline 1230 & Worked in a bank? & $\begin{array}{l}\text { YES } \ldots \ldots \ldots \ldots \ldots \ldots \ldots{ }^{1} \\
\text { NO } \ldots \ldots \ldots \ldots \ldots \ldots 2\end{array}$ \\
\hline 1240 & $\begin{array}{l}\text { Worked in a government office or in } \\
\text { the public sector? }\end{array}$ & $\begin{array}{l}\text { YES } \ldots \ldots \ldots \ldots \ldots \ldots \ldots{ }^{1} \\
\text { NO } \ldots \ldots \ldots \ldots \ldots \ldots \ldots 2 \\
\end{array}$ \\
\hline 1310 & Worked in a restaurant or hotel? & $\begin{array}{l}\text { YES } \ldots \ldots \ldots \ldots \ldots \ldots \ldots{ }^{1} \\
\text { NO } \ldots \ldots \ldots \ldots \ldots \ldots \ldots 2\end{array}$ \\
\hline 1320 & Worked in a factory or workshop? & $\begin{array}{l}\text { YES } \ldots \ldots \ldots \ldots \ldots \ldots \ldots{ }^{1} \\
\text { NO } \ldots \ldots \ldots \ldots \ldots \ldots 2\end{array}$ \\
\hline 1330 & $\begin{array}{l}\text { Sold something in the market or a } \\
\text { shop? }\end{array}$ & $\begin{array}{l}\text { YES } \ldots \ldots \ldots \ldots \ldots \ldots \ldots{ }^{1} \\
\text { NO } \ldots \ldots \ldots \ldots \ldots \ldots \ldots 2\end{array}$ \\
\hline 1340 & Sold something from home? & $\begin{array}{l}\text { YES } \ldots \ldots \ldots \ldots \ldots \ldots \ldots{ }^{1} \\
\text { NO } \ldots \ldots \ldots \ldots \ldots \ldots \ldots 2\end{array}$ \\
\hline 1350 & $\begin{array}{l}\text { Did construction work, such as } \\
\text { carried cement, bricks or sand? }\end{array}$ & $\begin{array}{l}\text { YES } \ldots \ldots \ldots \ldots \ldots \ldots \ldots{ }^{1} \\
\text { NO } \ldots \ldots \ldots \ldots \ldots \ldots 2\end{array}$ \\
\hline 1360 & Worked in someone else's home? & $\begin{array}{l}\text { YES } \ldots \ldots \ldots \ldots \ldots \ldots \ldots{ }^{1} \\
\text { NO } \ldots \ldots \ldots \ldots \ldots \ldots \ldots 2\end{array}$ \\
\hline 1370 & Did anything else similar? & $\begin{array}{l}\operatorname{YES} \ldots \ldots \ldots \ldots \ldots \ldots \ldots{ }^{1} \\
\operatorname{NO} \ldots \ldots \ldots \ldots \ldots \ldots 2\end{array}$ \\
\hline
\end{tabular}




\section{ELMS}

Immediately below are the work questions as used in the 1998 Egypt Labor Market Survey.

\begin{tabular}{|c|c|c|c|c|c|c|c|c|c|c|}
\hline \multirow[t]{4}{*}{$\begin{array}{l}\text { ID } \\
\text { Code }\end{array}$} & $\begin{array}{l}1501 . \\
\text { Did you participate } \\
\text { in any employment } \\
\text { during the last three } \\
\text { months ending } 31 \\
\text { October } 1998 ?\end{array}$ & \multicolumn{8}{|c|}{$\begin{array}{l}1502 . \\
\text { Did you participate during the last three months } \\
\text { ending } 31 \text { October } 1998 \text { for a short period or } \\
\text { irregular periods in any of the following activities? } \\
\text { (1) Yes } \\
\text { (2) No }\end{array}$} & $\begin{array}{l}1503 . \\
\text { Did you participate } \\
\text { in any agricultural } \\
\text { production, or } \\
\text { keeping of poultry } \\
\text { and livestock for } \\
\text { family } \\
\text { consumption? }\end{array}$ \\
\hline & $\begin{array}{l}\text { (1) Yes } \rightarrow 1505 \\
\text { (2) No }\end{array}$ & \multicolumn{8}{|c|}{$\begin{array}{l}\text { i. produce goods sold at shops or project } \\
\text { ii. offer paid services to others } \\
\text { iii. produce goods and selling it yourself } \\
\text { iv. buying goods and re-selling it yourself } \\
\text { v. independent paid work } \\
\text { vi. helping in family's business } \\
\text { vii. participate in project- agricultural, } \\
\text { or keep poultry and livestock } \\
\text { viii. learn a skill in a factory or garage } \\
\text { To Researcher: Read all options }\end{array}$} & $\begin{array}{l}\text { (1) Yes } \\
\text { (2) No }\end{array}$ \\
\hline & & I & II & III & IV & $\mathrm{V}$ & VI & VII & VIII & \\
\hline & & & & & & & & & & \\
\hline
\end{tabular}

1504. Have you ever worked before. If not, go to next person.

Once again, we maintain the basic introductory questions (1501) just as it was in the original survey. We have replaced the multiple keyword questions (Q1502) with our activities list. (Recall that the 8 keyword questions used in the 1998 ELMS questionnaire identified only 6 working women. Therefore deleting them has no meaningful impact on comparability across time.) Question 1503 about work in agriculture has been modified to emphasize the difference between work in the fields and animal husbandry, and to remove the restriction of primary production for "family consumption" that was included in the 1998 survey.

Note also that in the 1998 survey, once a person was identified as working, the remaining work questions were skipped. We would remove this skip, and identify all the types of work each person was involved with. 


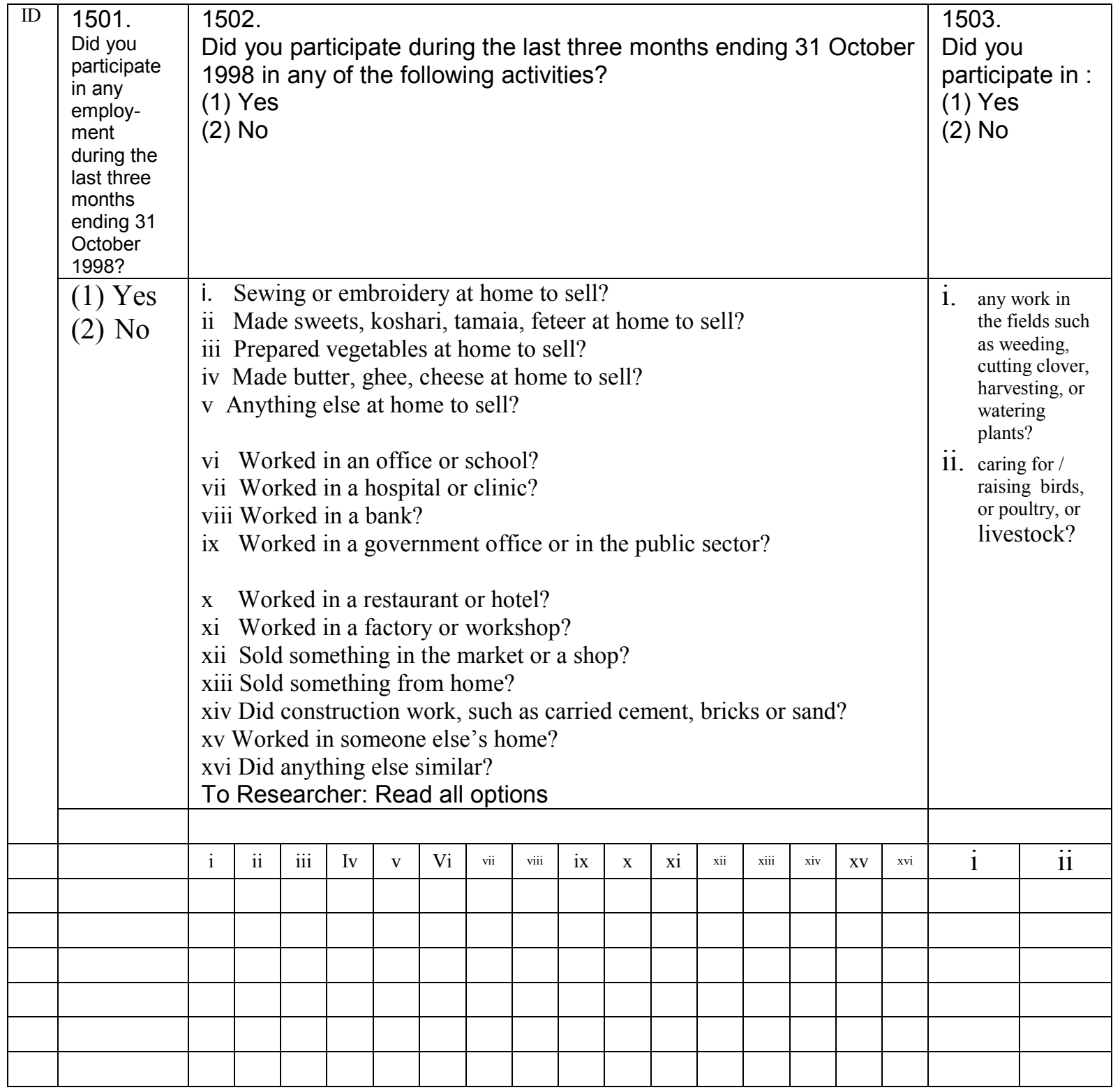

1504. Have you ever worked before. If not, go to next person.

\section{LSMS}

The standard LSMS questions combine the issue of working with the relationship of the respondent to the means of production. (That is, question 3 seeks to identify those employed by others. Questions 3 and 5 are targeted at those who work for their own account-business owners, independent workers. We believe that this approach is likely to cause confusion, and result in under-reporting of work. 


\begin{tabular}{|c|l|l|l|}
\hline CD & $\begin{array}{l}\text { 3. } \\
\text { During the past 7 days } \\
\text { have you worked for } \\
\text { someone who is not a } \\
\text { member of your } \\
\text { household, for } \\
\text { example, an enterprise, } \\
\text { company, the } \\
\text { government, or any } \\
\text { other individual? }\end{array}$ & $\begin{array}{l}\text { 5. } \\
\text { During the past 7 days } \\
\text { have you worked on a farm } \\
\text { owned or rented by a } \\
\text { member of your household, } \\
\text { whether in cultivating } \\
\text { crops, or in other farm } \\
\text { maintenance tasks, or have } \\
\text { you cared for livestock } \\
\text { belonging to a member of } \\
\text { your household? }\end{array}$ & $\begin{array}{l}\text { During the past 7 days } \\
\text { have you worked on your } \\
\text { own account, or in a } \\
\text { business enterprise } \\
\text { belonging to you or } \\
\text { someone in your } \\
\text { household, for example, as } \\
\text { a trader, shopkeeper, } \\
\text { barber, dressmaker, } \\
\text { carpenter, or taxi driver? }\end{array}$ \\
\hline 1 & & $\begin{array}{l}\text { Yes }=1>5 \\
\text { No }=2\end{array}$ & Nes $=1>7$ \\
\hline 2 & & & $\begin{array}{l}\text { Yes }=1>9 \\
\text { No }=2\end{array}$ \\
\hline 3 & & & \\
\hline 4 & & & \\
\hline 5 & & & \\
\hline
\end{tabular}

Questions about work in the last 12 months are interspersed: e.g. "During the past 12 months have you worked for anyone who is not a member of your household."

If 3,5,7 all "No", asked if "had a permanent job" even though not worked in last 7 days.

If no permanent job, asked if looked for work.

If not looked for work, asked if in last 12 months were "without work and looking for work".

If not worked in last 12 months (4,6,8-all "No"), go to next person.

In our revised LSMS format we have replaced each of the standard question with elements from the activities list that most closely correspond to the intent of the original question. Thus, in question 3 we have included activities that are likely to involve employees. But, we don't limit it to employees. For example, if someone works in an office, we want to know that whether they're the owner of the business, or the lowliest employee. Similarly in question 5, we ask about agricultural activities, but do not limit our responses to those who work on land or care for animals belonging to members of their household. We want to know about all agricultural workers. 


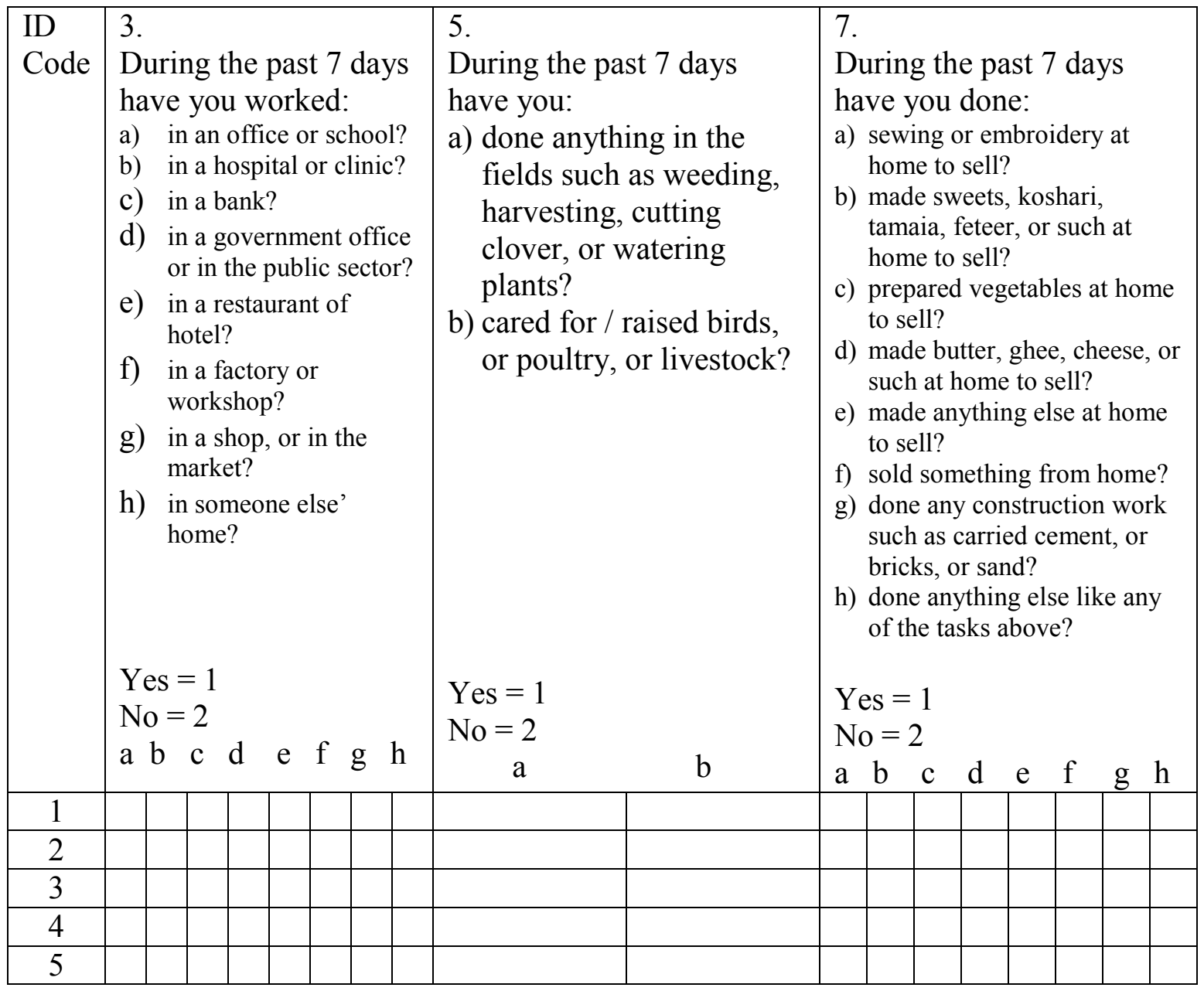

\section{SFT}

Finally below we show the SFT activities list as it appeared in it's structured format in the actual questionnaire. Questions identifying the main occupation when more than one activity was mentioned; and on hours worked; amount earned and its allocation to household expenses; etc are included just as examples. These questions could be modified to provide more appropriate information to the task at hand.

The SFT included no questions to determine whether the work is informal or contractual; has social security benefits or not; and whether the person is an owner or employee. These could be easily added. 


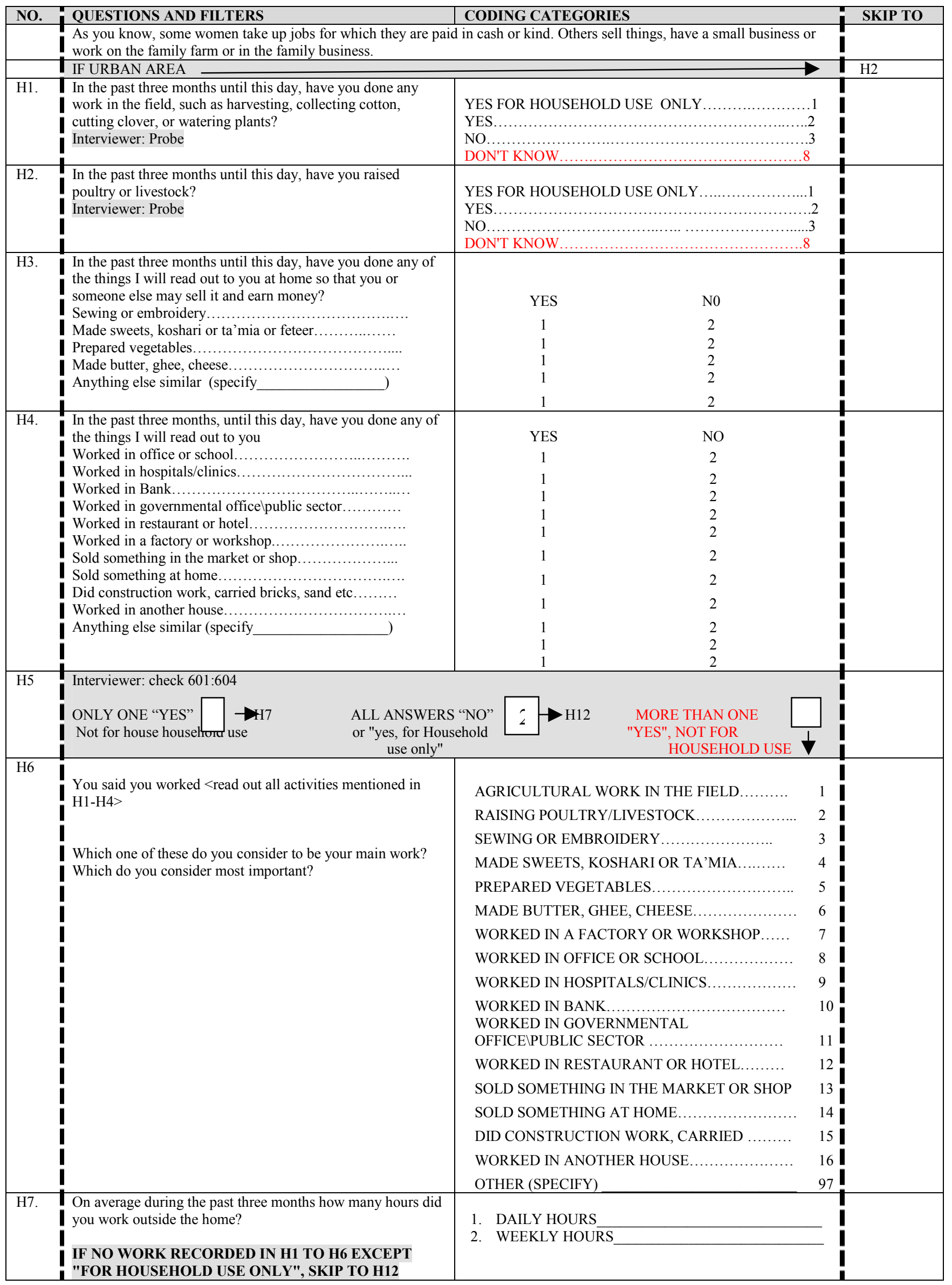




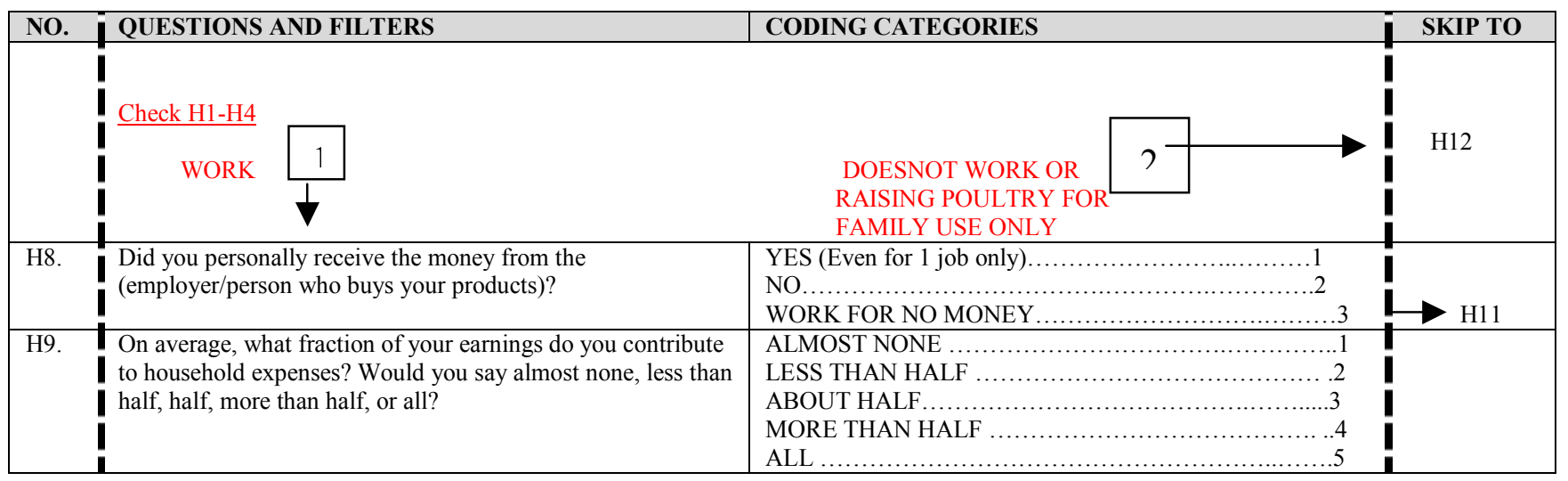

